
centrasiatiques et tibétaines

$51 \mid 2020$

Ladakh Through the Ages. A Volume on Art History and Archaeology, followed by Varia

\title{
Preliminary field notes on the ancient ceramics of Ladakh
}

Notes préliminaires de terrain sur les céramiques anciennes du Ladakh

Samara Broglia de Moura

\section{(2) OpenEdition}

Journals

Electronic version

URL: https://journals.openedition.org/emscat/4191

DOI: $10.4000 /$ emscat.4191

ISSN: 2101-0013

\section{Publisher}

Centre d'Etudes Mongoles \& Sibériennes / École Pratique des Hautes Études

Electronic reference

Samara Broglia de Moura, "Preliminary field notes on the ancient ceramics of Ladakh", Études mongoles et sibériennes, centrasiatiques et tibétaines [Online], 51 | 2020, Online since 09 December 2020, connection on 13 July 2021. URL: http://journals.openedition.org/emscat/4191 ; DOI: https:// doi.org/10.4000/emscat.4191

This text was automatically generated on 13 July 2021.

(ㄷ) Tous droits réservés 


\title{
Preliminary field notes on the ancient ceramics of Ladakh
}

\author{
Notes préliminaires de terrain sur les céramiques anciennes du Ladakh
}

\author{
Samara Broglia de Moura
}

\section{Introduction}

1 Ceramics are one of the fundamental materials in archaeology for the understanding of chronologies and cultural interactions; they are usually the most abundant material found in archaeological sites and, since shapes and techniques evolve over time, constitute one of the best elements at our disposal for the dating of a site. Furthermore, ceramics have proven to be important indicators of interactions between regions, providing crucial information about the groups at stake in areas of cultural diversity. Although Ladakh was a trading centre located at the intersection of major cultural complexes, and although at almost every archaeological site sherds of pottery are found, their potential for understanding Ladakh's rich history has so far not been properly explored.

2 This paper will give a brief overview of the research previously conducted in Ladakh on the topic, before introducing the fieldwork that I have been carrying out there since 2015. I will then present the types of ceramics found in the region in a chronological order, from Prehistory onwards, along with comparisons with neighbouring regions.

\section{Previous research on the ancient pottery of Ladakh}

The first report of ancient pottery in Ladakh was made in 1904 by August H. Francke (1994, p. 71) and Dr. Shawe, when they discovered several intact jars during the excavation of a tomb near Leh. Two of these jars had painted decorations and were described by Dr. Shawe (Duncan 1906, p. 148). According to him, the pots were made of a clay of drab colour, and were decorated with painted dark red "volutes". They were 
rather small in size, $10 \mathrm{~cm}$ in height, 7,6 cm in diameter around the rim and $10,1 \mathrm{~cm}$ in diameter around the body (fig. 1). Most of these ceramics were filled with human bones. In 1909, Francke wrote a report for the Archaeological Survey (ASI) announcing the discovery of a second nearby tomb (Francke 2002), which he characterized as belonging to the "Dardic" culture. The ceramics described by him were handmade (shaped without a potter's wheel) and of various sizes, several of which showed impressed linear ornaments (Francke 1994, pp. 71-72).

Figure 1. Painted pottery discovered by Francke and Shawe in a grave near Leh, Ladakh
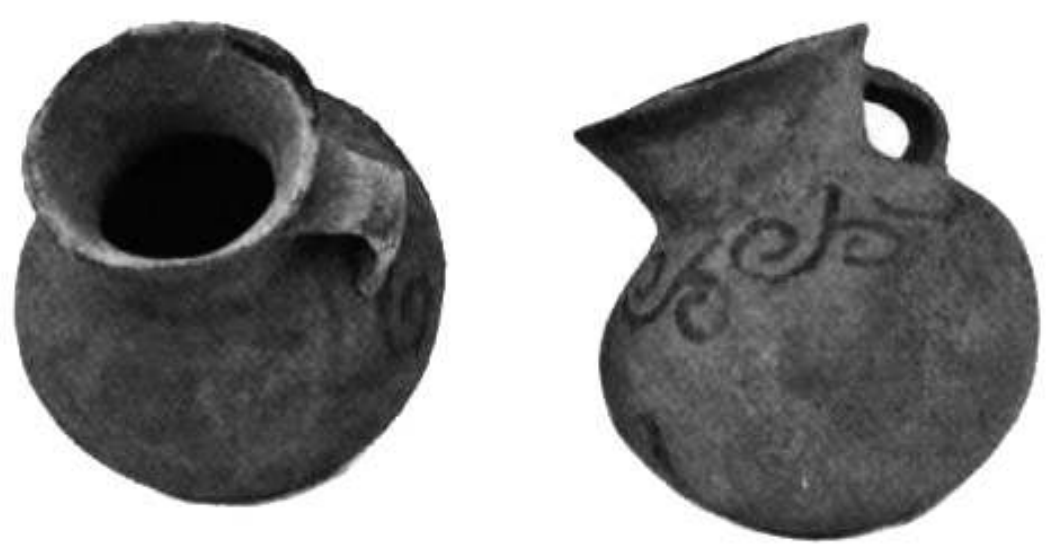

(C) Rev Dr Shawe (from Duncan 1906, p. 148)

Francke (1994, p. 74) tried to establish a chronology for the funerary context of the ceramics, with arguments that would nowadays be avoided: he compared the type of burial $^{1}$ of the skeletons from Leh with those from the "Empire of Eastern Women" described in the Sui Shu ${ }^{2}$ and by Hiuen Tsiang ${ }^{3}$ (Beal 1884, p. 199), and concluded that the grave and its materials were datable to the first half of the $1^{\text {st }}$ millennium $\mathrm{CE}^{4}$.

In 1904, Francke (1905) also found several sherds of painted ware at the site of Balumkhar. Accord to him, the jars were similar in shape to those found at the grave in Leh, but here they were ornamented with red pigments. Duncan added that the jars of the grave excavated in 1904 and those from Balumkhar had the same colour ${ }^{5}$ (Duncan 1906, p. 147). In 1906, Francke (p. 325) published the discovery of painted pottery from the Alchi fort, where he had found two sherds with red designs similar to those from Balumkhar. Francke (1994, p. 117) mentioned that the sherds from Alchi were sent to Shimla, but it seems that at least eleven sherds of the painted pottery from Alchi were sent to the Pratap Singh Museum in Srinagar.

6 After the work of Francke, it took almost 80 years for a new publication to appear on the subject. Neil Howard briefly mentioned a variety of painted pottery he found in the fortified sites he visited for his 1989 article on the fortresses of Upper and Lower Ladakh (Howard 1989, pp. 223-226). He presented a first critical analysis of the chronology proposed by Francke for the graves. Unconvinced by a pre-Tibetan date, Howard stated that most of the painted sherds found in fortified sites dated, according to him, from around the $10^{\text {th }}$ century CE. The term "Dard" applied by Francke on many 
occasions to describe the culture of the graves was also criticized, as Howard did not agree with the use of such identification in view of the absence of factual evidence. According to him, the tombs could just as well have belonged to any of the many cultural groups that have lived side by side in Ladakh over the centuries, and they could also have been made by any of the numerous travellers that passed through the region in the historical period (Howard 1999, p. 226).

Howard also wrote an article dedicated to painted pottery in 1999. After conducting surveys in nine sites in Upper and Lower Ladakh and studying their painted ceramics, the author categorised them into two main groups: the ones from Lower Ladakh he called "Lower Ladakh delicate style", and those from Upper Ladakh he regarded to be coarser. The majority of those sherds were discovered in fortified and monastic sites. The chronology he elaborated extended from the $8^{\text {th }}$ to the $16^{\text {th }}$ century CE; it was primarily based on data from the Balumkhar fort, as this site had sherds from the beginning and from the end of his chronological framework ${ }^{6}$. Additionally, Howard mentioned a handful of sites with painted pottery from the Chemre valley that he dated to the $17^{\text {th }}$ century.

In 1993, S. B. Ota (p. 103) briefly mentioned the pottery discovered in a stratigraphic trial pit excavated in Kiari (Changthang) and dated to 900 BCE. The only rim published was described as handmade and showed similar features to the pottery recovered from the Neolithic site of Burzahom in the Kashmir valley for Period II (2500-1700 BCE) (Anonymous 1964, p. 20 and p. 27, fig. 6). Despite the fact that the rim from Kiari was compared with a neck from Burzahom that does not have a similar shape, it is still the only one in Ladakh for the period that was documented in a stratigraphic context.

Between 2002 and 2014, Martin Vernier and Quentin Devers collected ceramics from all parts of Ladakh in the course of their own research, and these were handed over to the ASI after the Franco-Indian Archaeological Mission in Ladakh (or MAFIL) was created in $2013^{7}$. In the first two years of its work, MAFIL undertook the documentation of a number of sites in Nubra, from which it collected further ceramics, and also conducted a study on both the ceramics previously collected and those they were collecting themselves, focusing exclusively on the Nubra region. This research, led by Aurore Didier $^{8}$, analysed 1200 sherds from 22 locations (Bruneau 2013, p. 24), and resulted in the creation of a general typo-chronology extending from the Neolithic period to the Namgyal Dynasty ${ }^{9}\left(16^{\text {th }}-19^{\text {th }}\right.$ century CE). This research brought to light a number of important new elements, such as the presence of possible post-Kushan ceramics, which opened up new perspectives for the exploration of the history of the valley.

As a summary, we can say that since the first publication of archaeological ceramics in Ladakh, at the beginning of the $20^{\text {th }}$ century, very few studies have been carried out on the topic. The only detailed scientific analysis of this important material was conducted in 2013 and showed the potential of such a study, but was unfortunately restricted to the Nubra valley. It is in light of this state of affairs that I decided to undertake the following study, to explore the research potential of ceramics in the other parts of Ladakh and see what information they could provide about the overall history of the region. 


\section{The archaeological surveys and study of ceramics}

11 The pottery collected by Devers and Vernier (excluding the sherds from Nubra valley, which were already studied by Didier) was investigated in 2015, 2016 and 2018 by the author at the ASI's office in Ladakh ${ }^{10}$ (Mini Circle Leh). In the course of this study, it became evident there was a need for a better understanding of the archaeological contexts of these sherds. Also, in a number of cases too few sherds had been collected, calling for new surveys in order to create more adequate sample sizes. As a result, a series of surveys was carried out from 2015 to 2018, visiting the following sites:

- In Lower Ladakh: Wanla (fortified complex), Saspol (caves and fort), Basgo (fortified complex Ratan Lhatse Khar), Phyang (fortified complex Tselam Khar), Balumkhar;

- In Upper Ladakh: Phey (fort 2 and funerary site), Spituk (funerary site), Sabu Phu (ruined settlements), Stok (funerary site), Nyarma (temples), Sakti (fortified complex), Takkar (Rama Ruchik Khar), Stagna (Sumarati khar), Khyangar Khar (fortified complex), Leh Choskhor (religious complex);

- In Changthang: Staglung (fortified settlement and funerary site), Nyoma (fortified complex and funerary site), Tangtse (fortified complex);

- In Zanskar: Tsazar (funerary site), Zangla (fortified complex and cave complex);

- In Purig: Dras (the fortified complexes of Rgyalmo Khar, Goshan Khar, Biru Khar and Lamo Chen khar), Phikhar (ruins of Pikhar).

Prior to these surveys, the corpus of sherds collected by Devers and Vernier in the valleys outside of Nubra comprised 1122 sherds coming from 35 archaeological sites. Of these, 232 sherds were diagnostics, i.e. they provided information concerning the overall type, shape, technique or decoration of the original pottery. This corpus was then updated with an additional 3488 sherds (including 824 diagnostics) coming from an additional 25 sites. In total, 4610 sherds $^{11}$ from 60 archaeological sites were studied over these four years, both at the ASI office in Leh and on site during the field surveys (fig. 2). The study of these potteries aimed at creating a categorization based on morphological types (Balfet et al. 1983, 1988), technical features ${ }^{12}$ and decoration categories along with a systematic documentation.

On the basis of this study and factoring in the archaeological contexts of the sites where the sherds were found, a broad chronological framework could be worked out. However, it must be borne in mind that this research is still on-going and based on - by archaeological standards - very limited data; over time, new data and analyses will surely modify and improve this chronology. 
Figure 2. Location of the 60 archaeological sites studied in the five sub-regions of Ladakh

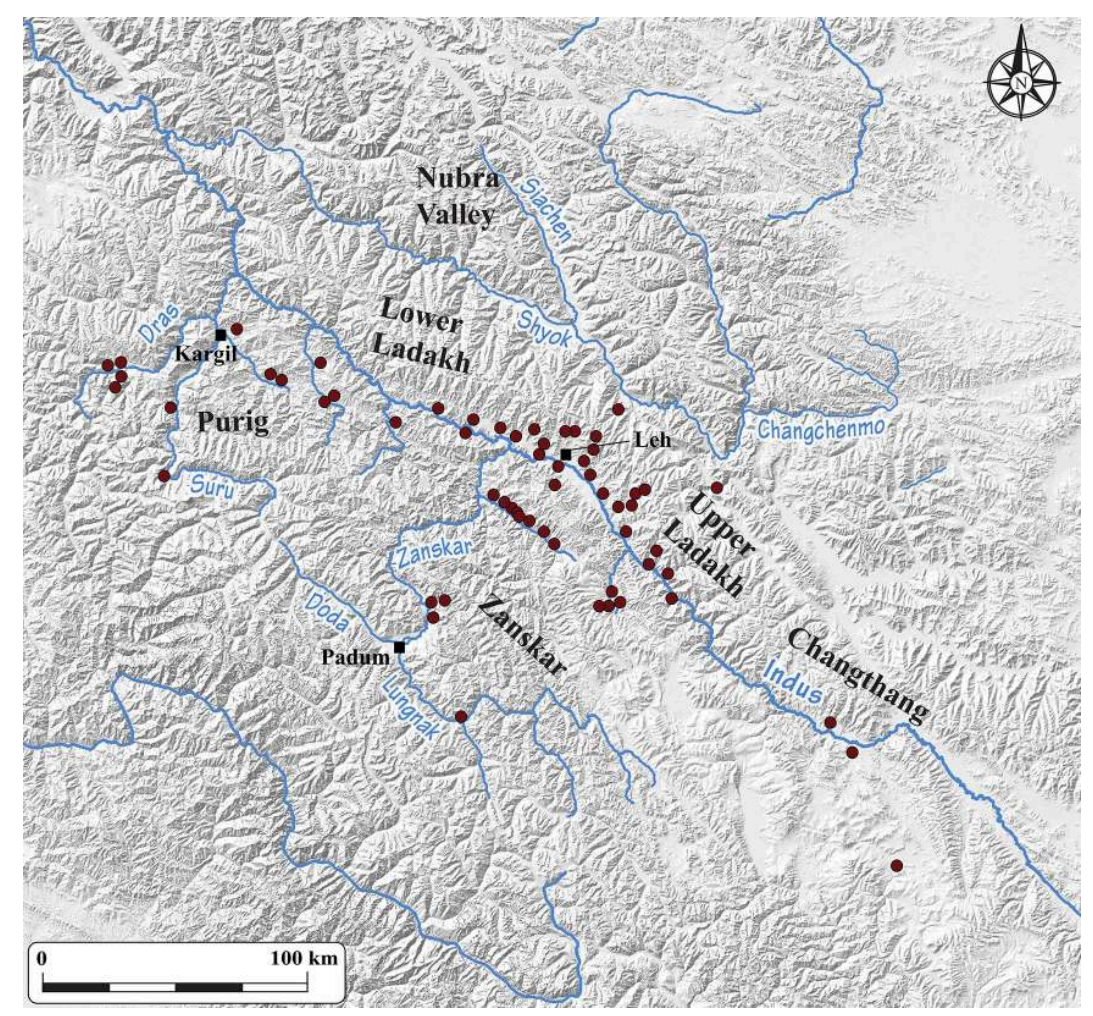

(c) Samara Broglia de Moura, 2018; map background Quentin Devers, 2016

\section{Prehistory}

For the purpose of this study, "Prehistory" is defined as ending with the beginning of the Bronze Age, which, in Central Asia, is considered to start around the $3^{\text {rd }}$ millennium BCE and, in regions such as Kashmir, after the $2^{\text {nd }}$ millennium BCE. However, the chronological limits for the prehistoric period in Ladakh remain to be properly assessed, since the Neolithic site of Kiari was dated to $900 \mathrm{BCE}$ - as mentioned before.

There are almost no ceramics that could be assigned to Prehistory in the collection at our disposal, as research for this period in Ladakh is still at its beginning. Considerable progress has, however, been made by the ASI ${ }^{13}$ and by MAFIL in recent years. In Tirisa (Nubra), a prehistoric open-air site centred on a lake yielded important discoveries. First documented by R. S. Fonia (1993) and subsequently by Claire Gaillard (Bruneau 2013, pp. 15-19), the shores of the lake are scattered with significant numbers of stone tools, among which a single sherd coming from a jar was observed, which had a flat rim and a horizontal band under it. A comparable rim was documented in Burzahom in Kashmir, where it was dated to the Neolithic period ${ }^{14}$ (Phase I-II). Another site, in Wakha (Purig), shows similarities with Kashmiri pottery: the sherd of a flat base with mat impressions (fig. 3) can be compared with ceramics from Kashmiri Neolithic sites, such as Burzahom and Gufkral, where mat impressions on flat bases are observed during phases II (2500-1700 BCE) and IC (2000-1700 BCE) respectively (Anonymous 1964, pp. 17-21; Anonymous 1965, pp. 9-10; Sharma 2013; Bandey 2009). So far, in the various publications on the Neolithic sites of Ladakh, such as Kiari and Giaki (Ota 1993), no pottery with such impressions has been described. 
Figure 3. Sherd with mat impressions from Wakha in Purig, Ladakh

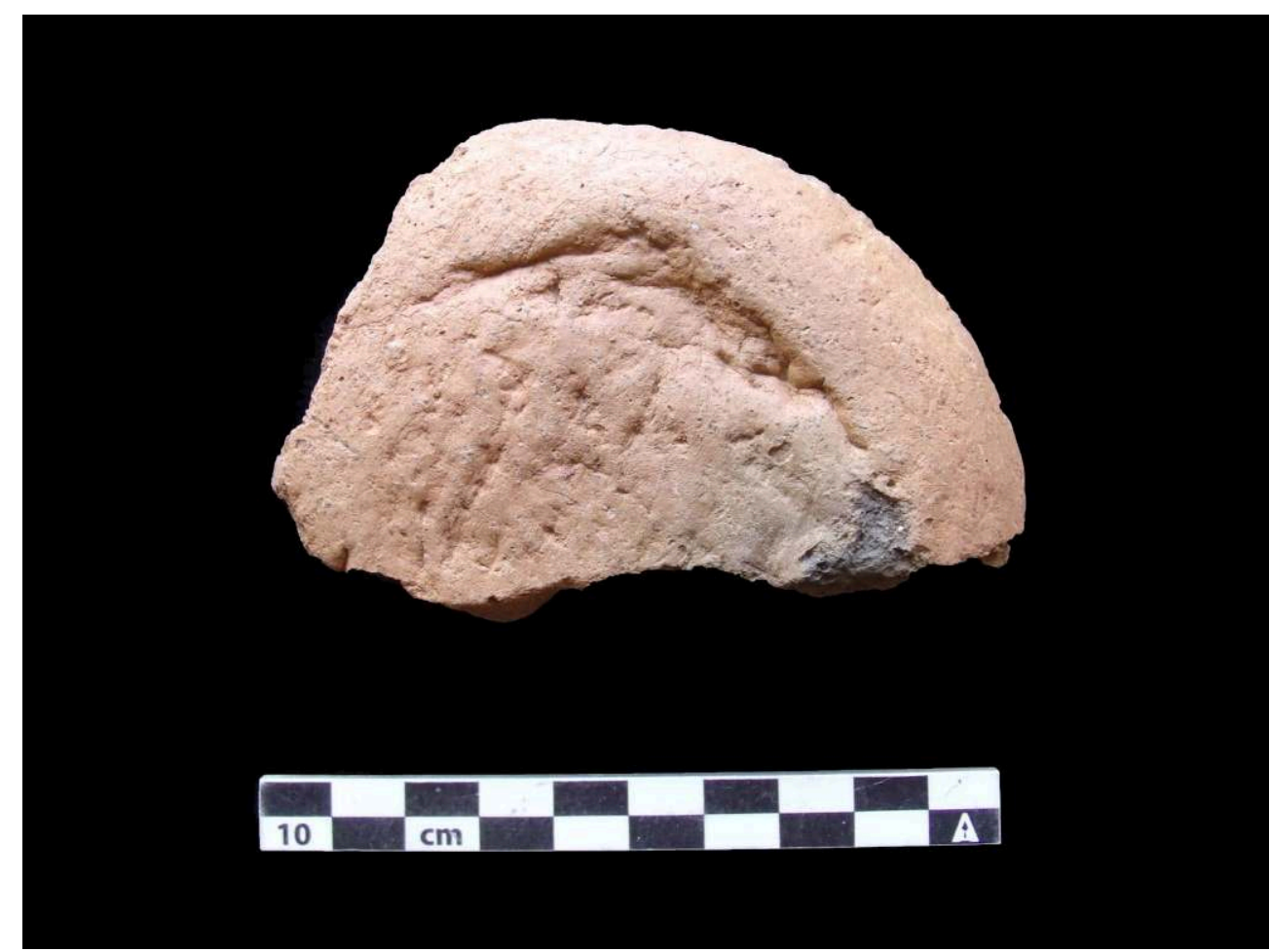

(C) Samara Broglia de Moura, 2016

Didier also highlighted a few sherds from the funerary site of Panamik-Hargam in Nubra, characterised by textile impressions comparable to the Neolithic material from Kashmir ${ }^{15}$. Other examples of textile impressions were found in Zangla ${ }^{16}$ (Zanskar) and in Chigtan and Wakha (Purig). Textile impressions on ceramics are still very difficult to date accurately, since they are also found in several Bronze and Iron Ages sites in Central Asia ${ }^{17}$.

\section{Protohistory: Western Himalayan influence}

17 In Ladakh, the period following Prehistory has been designated under the term of Protohistory. During this period two main traditions are observed, being in rock art, architecture, or other types of material remains: from Central Asia and from the Western Himalayas. As we will see, these main traditions are also noticeable in the study of ceramics. Because of these two dominating material traditions, we are led to use two parallel chronological terminologies: "Protohistory" for the Western Himalayan traditions of the time, and Antiquity/Late Antiquity for the Central Asian traditions happening in parallel.

18 Indeed, different chronological systems are used for the study of the Tibetan Plateau and of the Western Himalayas on one hand, and of Central Asia on the other. For instance, while the period extending roughly from the $3^{\text {rd }}$ century BCE to the $8^{\text {th }}$ century CE is commonly designated as "Antiquity" and "Late Antiquity" in Central Asia, it is commonly known as "Protohistory" on the Tibetan Plateau. As such, when 
studying Ladakh, we are led to handle both chronological systems, depending on which tradition one is looking at.

Two groups of ceramics exhibiting similarities with pottery from several parts of the Western Himalayas are observed in Ladakh for Protohistory. The first group is characterized by cord impressions, found especially on the body and on the base of the pottery. Ceramics from this group have up to now only been found in Changthang (in Staglung ${ }^{18}$ ), Upper Ladakh (in Spituk, Phey and Gya) and Zanskar (in Tsazar, Cha and Malakartse) (fig. 4). All these sites seem to be graveyards ${ }^{19}$, indicated by depressions in the ground as in Staglung, Phey and Cha (fig. 5), or as circular or rectangular arrays of stones as in Tsazar, Gya and Spituk (fig. 6).

Figure 4. Sites in Upper Ladakh, Zanskar and Changthang with the presence of corded ware

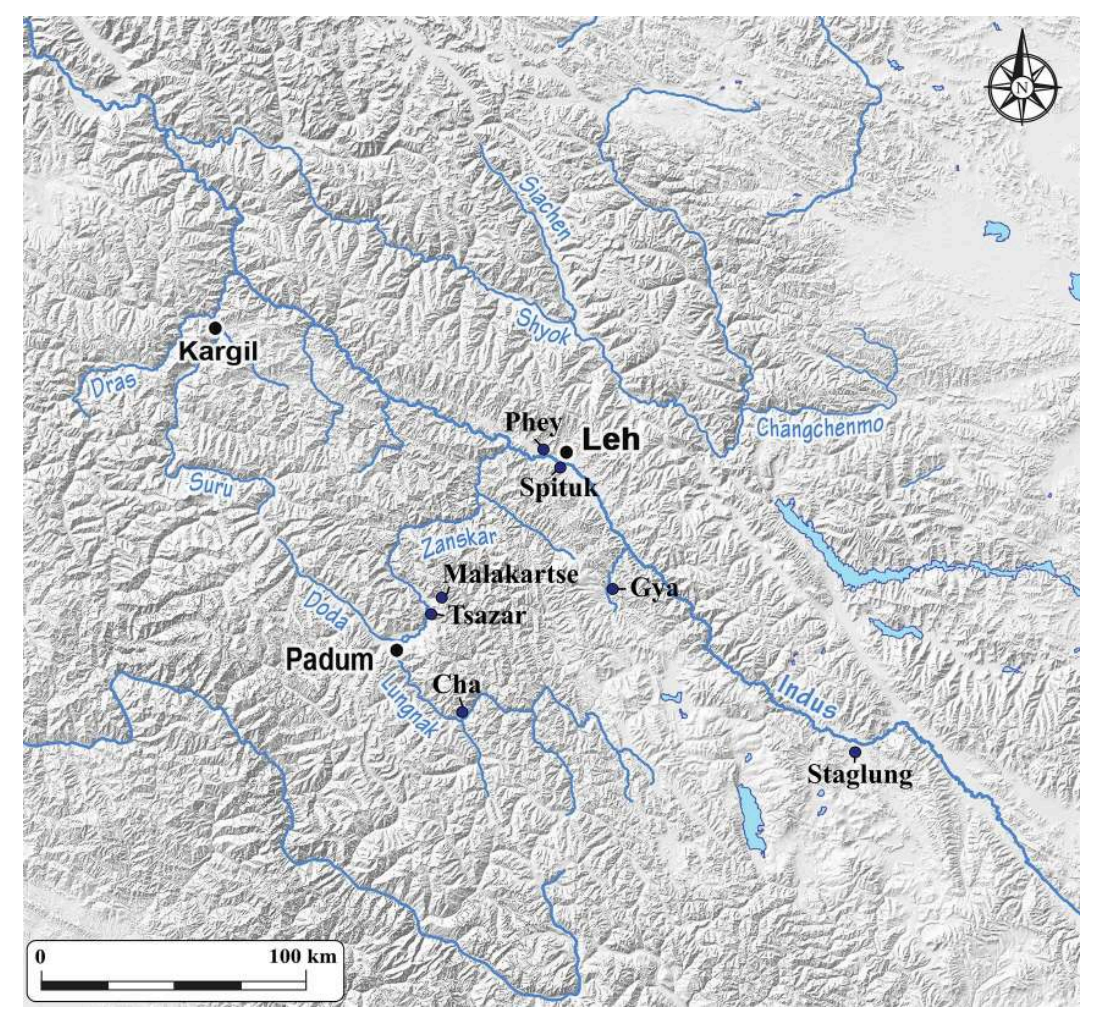

(c) Samara Broglia de Moura, 2018; map background Quentin Devers, 2016 
Figure 5. Site of Staglung in Changthang, Ladakh, viewed from the top of the fortification. The small white dots represent the graves

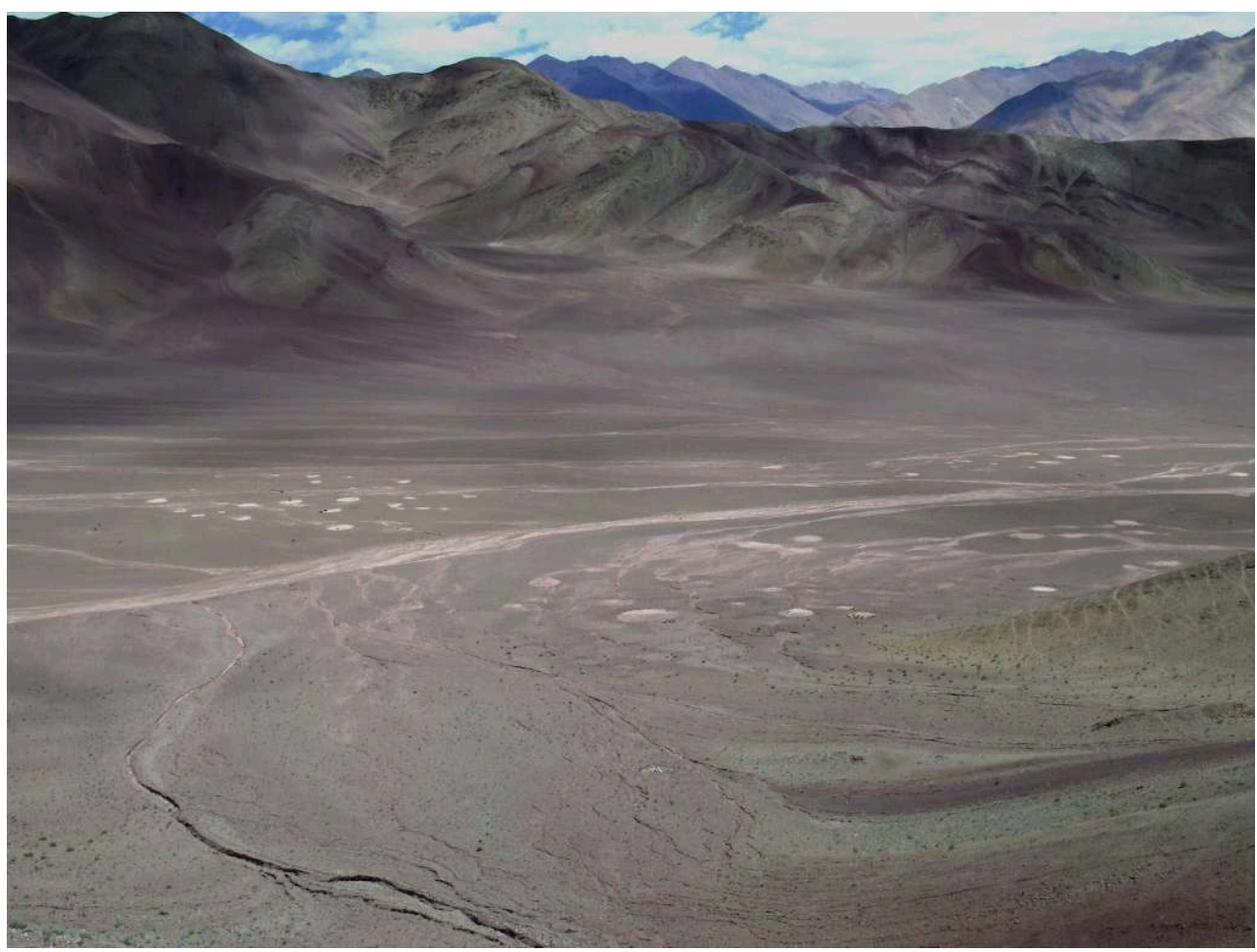

(c) Samara Broglia de Moura, 2016

Figure 6. A burial site at Tsazar in Zanskar, Ladakh

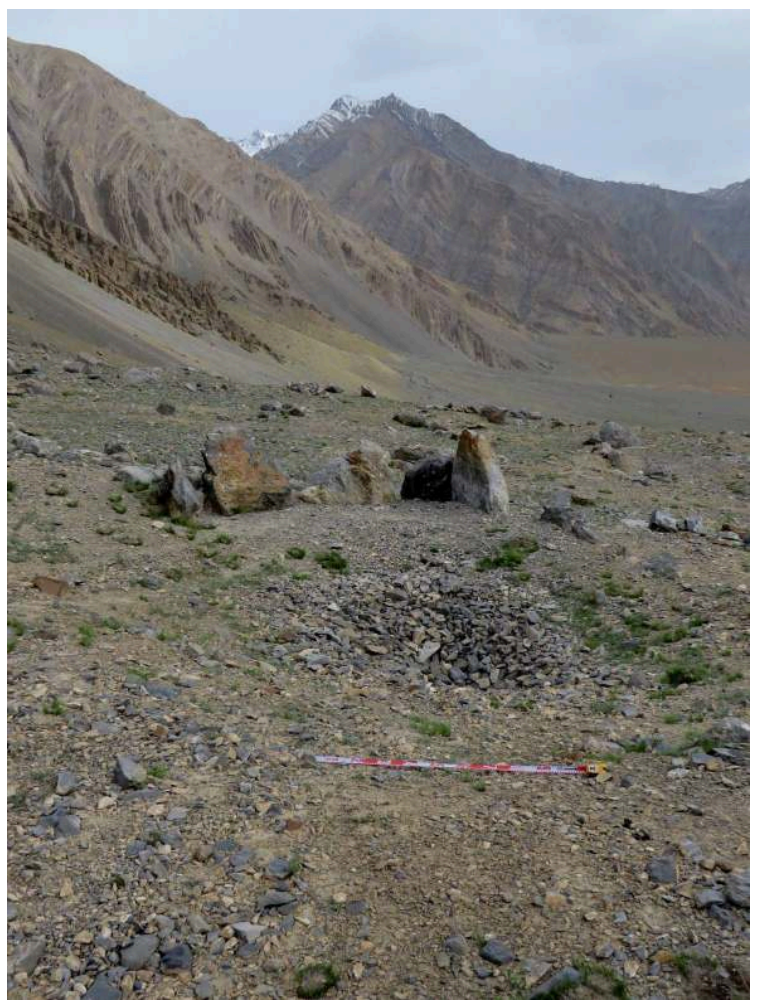

(c) Samara Broglia de Moura, 2017 
Most of the ceramics from these sites have been shaped by using a paddle wrapped with a cord; resulting in cord impressions left on their outside (fig. 7). Since this technique requires supporting the inner wall of the pot against the pressure of the paddle, these ceramics also have specific flat marks on their inner walls. Cord impressions usually run vertically and diagonally, and the majority are impressed under the neck. Several types of cords were used, with thicknesses varying from $0,5 \mathrm{~mm}$ to $3 \mathrm{~mm}$. Thick cords were so far observed only in Staglung and Gya, while ceramics from the other sites only have traces of thin cords.

Figure 7. Examples of sherds with cord marks from Ladakh (not to scale)

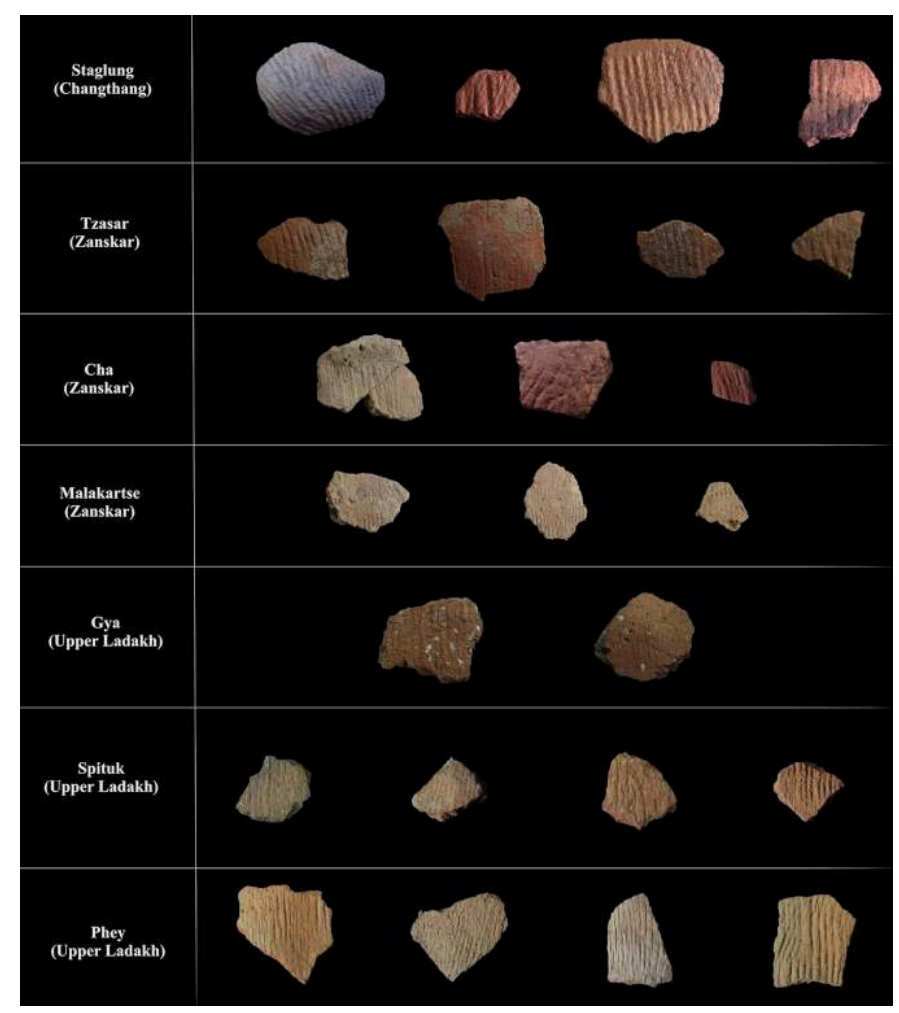

(C) Samara Broglia de Moura, 2019

Besides corded ware, which is the most common Western Himalayan type of ceramics during Protohistory, the first examples of painted ware occur during this period. For instance, the piece found by Francke in a grave in Leh in 1904, with volute motifs painted in red, is of similar design to the ceramics found in the site of Chuvthag in Western Tibet ( $2^{\text {nd }}$ to $3^{\text {rd }}$ century $\mathrm{CE}$ ). In the latter, we find both corded impressions and painted motifs on the same pots (Chinese Institute of Tibetology 2015, p. 41). This West Tibetan connection corroborates the doubts previously expressed by Howard (1999, p. 225) and Clarke (1977, p. 341) concerning the attribution by Francke of the ceramics excavated in Leh to the Dards Furthermore, the overall shapes of these pots from Leh are very similar to those of corded wares in general. It is possible that the "linear ornaments impressed" observed by Francke (1994, p. 72) actually correspond to cord marks - but only a new study of the pots could confirm $i^{20}$. 
Corded wares mostly have globular bodies, round bases, and medium to high necks. The rims are typically round, pointed or flat (fig. 8). A ware belonging to this category with an intact full section was observed in Gya near a pre-Buddhist funerary site ${ }^{21}$ (fig. 9).

Figure 8. Typology of the vessels from Staglung, Tsazar, Cha, Phey and Gya, Ladakh

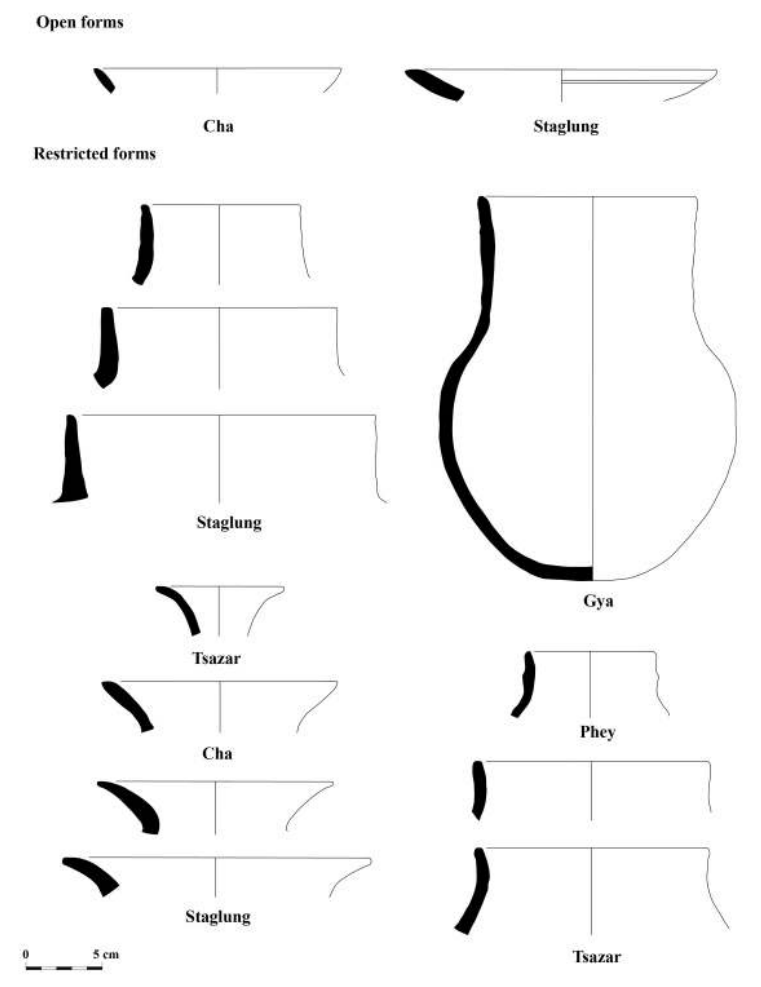

(c) Samara Broglia de Moura, 2019 
Figure 9. Corded ware in situ at Gya, Ladakh

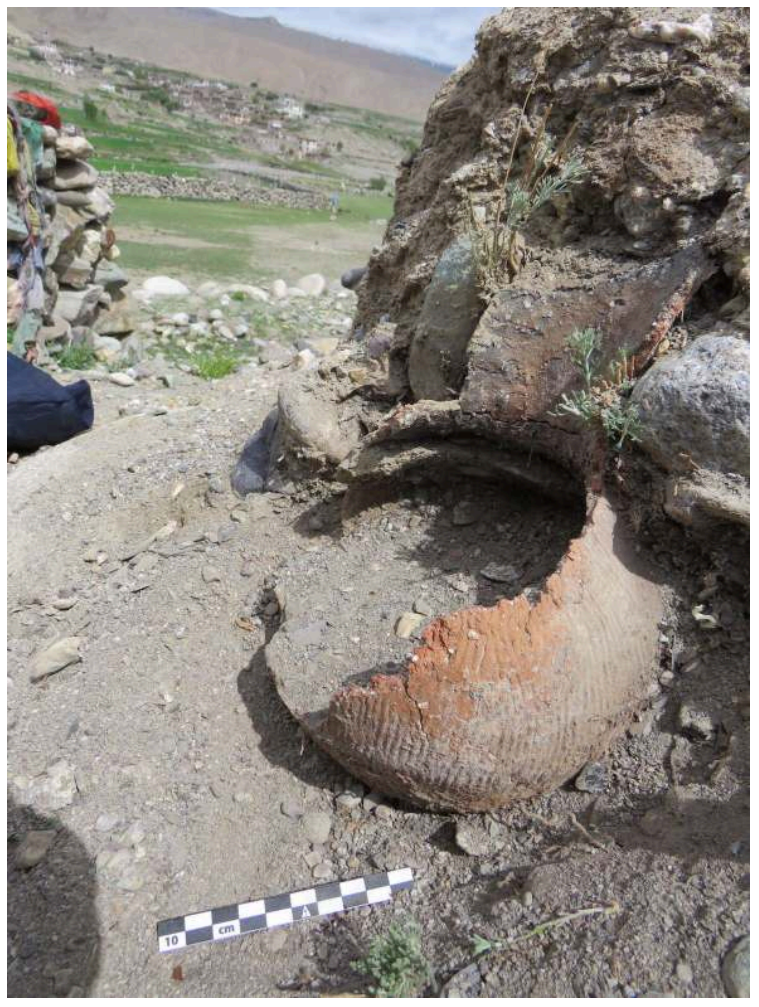

(C) Samara Broglia de Moura, 2017

Beyond Ladakh, corded ware is found in Western Tibet (Chuvthag and Gurgyam ${ }^{22}$, Dindun $^{23}$ and Phyang Dungkar ${ }^{24}$ ), in Mustang (Khyinga ${ }^{25}$, Chokhopani ${ }^{26}$ and Mebrak ${ }^{27}$ ), in Spiti (16 sites in the Spiti and Pin valleys ${ }^{28}$ ), and in Uttarakhand (Malari $\left.{ }^{29}\right)$. The map in figure 10 shows the distribution of these findspots over the Western and Central Himalayas. 
Figure 10. Sites with the presence of corded ware in Ladakh, Western Tibet, Uttarakhand, Spiti and Mustang

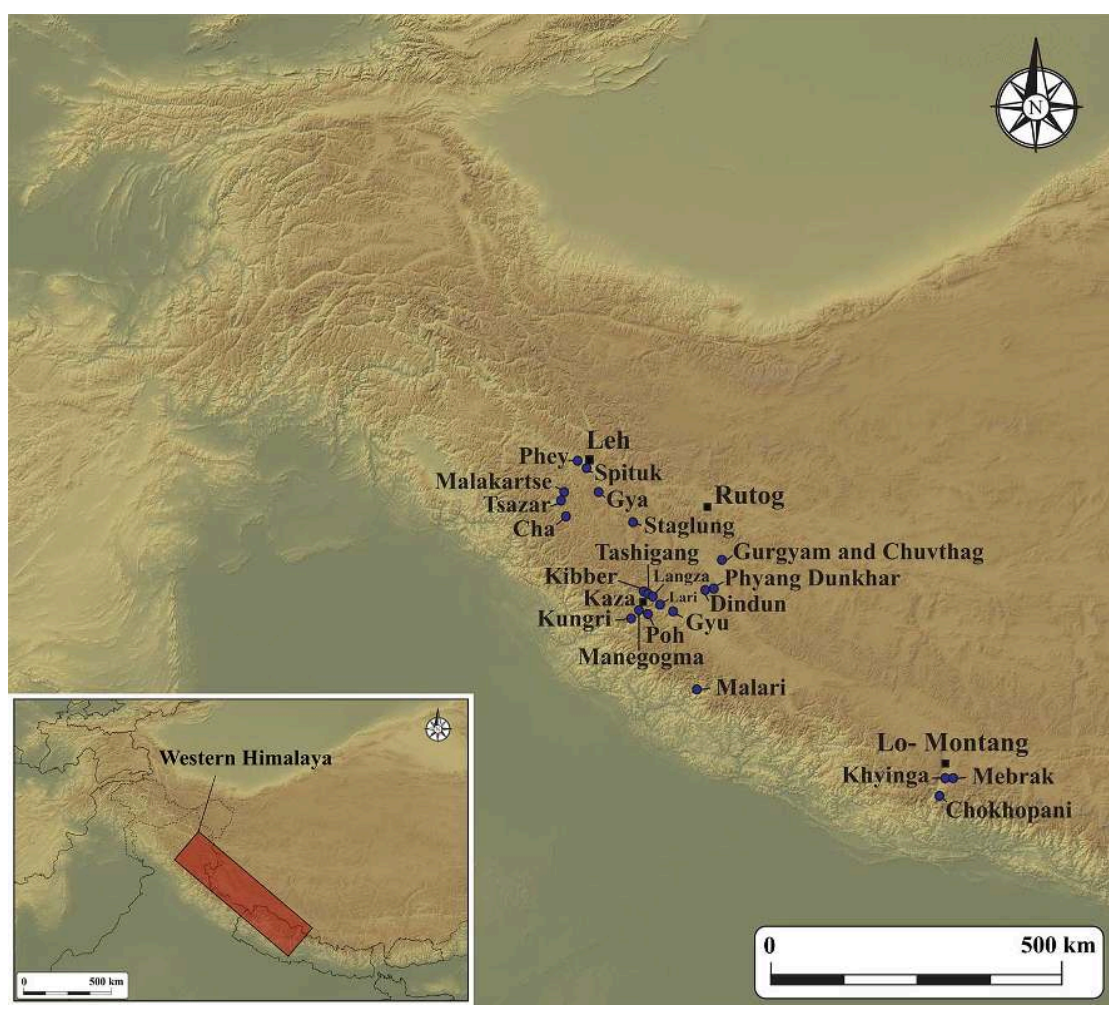

(c) Samara Broglia de Moura, 2018; map background Quentin Devers, 2016

In these regions, corded ceramics were mainly found in funerary contexts - just it seems in Ladakh. Nevertheless, in Mustang and in Western Tibet, corded ware is also found in residential sites as in Khyinga (Mustang) or Dindun (Western Tibet). In all these regions, paddles seem to have been used for shaping ${ }^{30}$, whereas the use of thin strings $(1 \mathrm{~mm})$ is observed in virtually all sites across the Western Himalayas, thicker cords (between $2 \mathrm{~mm}$ and $3 \mathrm{~mm}$ ) are seen only in few places: in Staglung and Gya (Ladakh); Kibber, Kungri, Lagza and Poh (Spiti); and Khyinga (Mustang). According to Papp's study ${ }^{31}$ (2002, pp. 60-65) the size of cords varies over time and can therefore indicate a chronology. It would be interesting to investigate if these chronological patterns are also valid in Ladakh.

The typology of corded ware in these other regions is similar to that in Ladakh: they too are defined by globular bodies, round bases, and middle to high necks. In Spiti, Uttarakhand and Western Tibet, pots with one or two handles and clearly-shaped spouts are also found. So far, open forms such as bowls are known only in Spiti valley (Tashigang graves), Western Tibet (Ghuvthag graves) and Ladakh (Staglung and Cha).

Though more research is needed to fully understand the origin and diffusion of corded ceramics over the Western Himalayas, the following outline can be put forward based on available data:

- The oldest corded ceramics, dated to the $5^{\text {th }}$ century BCE, were found in Western Tibet (primarily in Phyang, Dunkhar area and Dindun). Other early examples in Mustang (from tomb F 2006 in Khyinga) were dated from the $4^{\text {th }}$ to $2^{\text {nd }}$ century BCE; 
- A similar typology later appears in Uttarakhand (Malari) around the $1^{\text {st }}$ century BCE. In other parts of Western Tibet, such as Chuvthag and Gurgyam, corded ware appears in later periods only, around the $2^{\text {nd }}$ or $3^{\text {rd }}$ century CE;

- Late examples from around the $4^{\text {th }}$ century CE and even $6^{\text {th }}$ century CE were found in Mustang (respectively Khyinga and Chokhopani). The latest known instances of corded ceramics were observed in Spiti (Kibber) and date from around the $8^{\text {th }}$ century CE. spread towards the neighbouring regions of Uttarakhand, Spiti, Ladakh and Mustang. The core of this corded ceramics culture seems to lie in Western Tibet and Spiti, where the number of sites and the concentrations of ceramics are far higher than in Ladakh and Mustang (data in Uttarakhand are too fragmentary to assess the situation of corded ware there). This is of course only a first outline, based on insufficient data as only few sites have so far been excavated in the Western Himalayas in general. This overall image will undoubtedly be refined as more excavations and dating are carried out.

\section{Antiquity and Late Antiquity: Central Asian influence}

As already explained, the terms "Antiquity" and "Late Antiquity" - commonly used for the study of the history of Central Asia - has so far not been used for the study of the history of Ladakh. However, the material evidence shows that some parts of Ladakh, in particular Purig, had traditions connected with the Central Asian world during these periods.

Ceramics discovered in Purig indeed present technological and typological elements very comparable to Central Asian ceramics; they differ significantly from those found in the rest of the Western Himalayas. We will here focus on their technical and stylistic aspects. Some of this pottery from Purig was made on a slow wheel with a levigate fine paste with few and small size mineral inclusions, a technique that has rarely been observed in the rest of Ladakh. Also, the main finishing was carried out using a red or orange burnished slip ${ }^{32}$, another technique very rare in Ladakh. This was observed in Purig in several of the fortifications of Dras (Goshan Khar, Rgyalmo Khar, Biru Khar, Lamo Chen Khar), in Sanku, Chigtan, and Mulbek, and also at one site in Nubra (Bruneau 2014, p. 25), at Diskit (fig. 11).

Études mongoles et sibériennes, centrasiatiques et tibétaines, 51 | 2020 
Figure 11. Sites with the presence of burnished slip in Ladakh

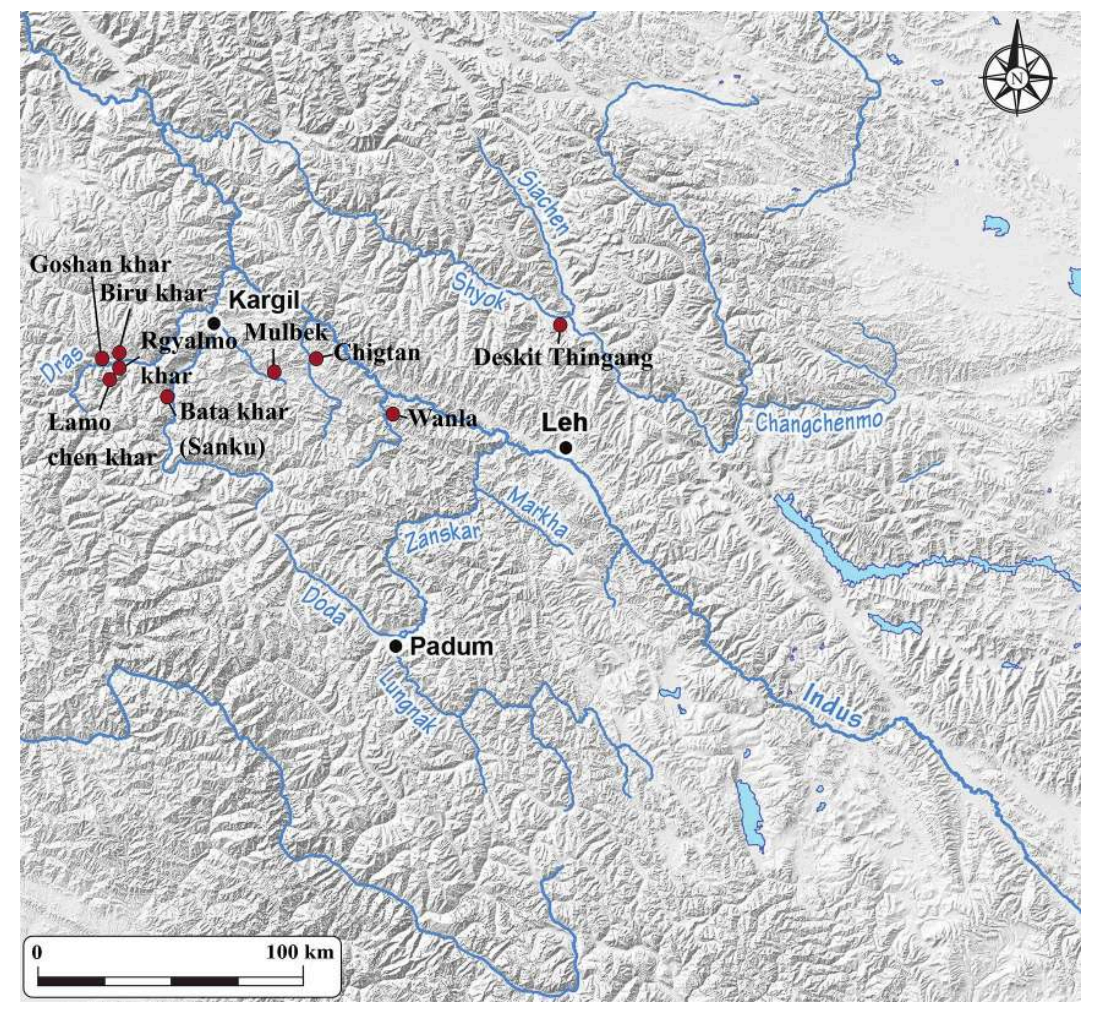

(C) Samara Broglia de Moura, 2018; map background Quentin Devers, 2016

31 At Goshan Khar, in Dras, incised ceramics with red, orange and black slip are decorated with wave patterns alternating with horizontal lines (fig. 12). This type of pottery, found in the historic Bactrian region (southern Uzbekistan, northern Afghanistan and western Tajikistan), is normally dated to the Kushan and Kushano-Sasanian periods ( $1^{\text {st }}$ to $4^{\text {th }}$ century CE) (Lyonnet 1997). The type of black slip sherd with light paste found in Goshan Khar was, according to Lyonnet, common at the beginning of the Kushan period in Bactria. It was probably a substitute for the grey ware found in the Hellenistic period, and which disappeared during the reign of the great Kushans (Lyonnet 1997, pp. 174-175). 
Figure 12. Sherds with wave pattern decoration under black and orange burnished slip from Goshan Khar, Dras Valley, Ladakh

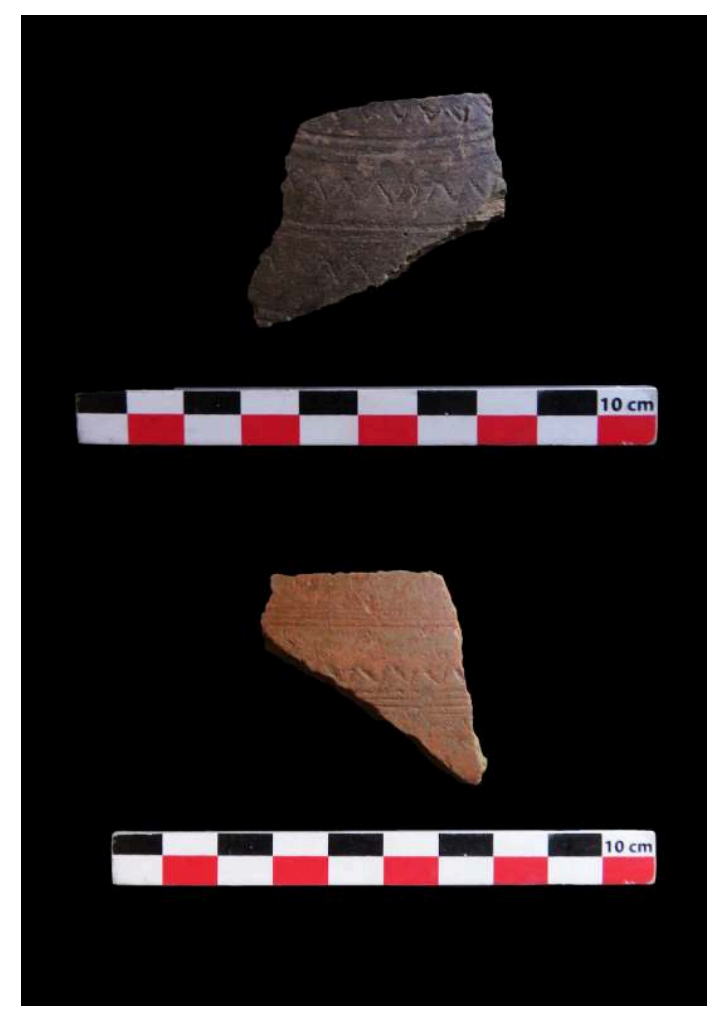

(C) Samara Broglia de Moura, 2017

Central Asian traditions are also attested in Rgyalmo Khar (Dras), with sherds decorated with stamped rosettes (fig. 13). Such stamped ware was very common in the Kapisi-Kabul-Ghazni region in Afghanistan, for instance in sites such as Begram (Ghirshman 1946; Kuwayama 1974b, 1991, 2002), Tepe Narenj (Paiman 2013), Tepe Sardar (Taddei 1968), Tepe Maranjan (Hackin et al. 1959), Mes Aynak (Engel 2012 and Lerner 2018), Shotorak (Meunié 1942), Gul Dara (Fussman \& Le Berre 1976), Saka fort (Hackin et al. 1959), Khona Masdjid (Veuve 1974), Chacalaq Tepe (Higuchi \& Kuwayama 1970), Tepe Skandar (Kuwayama 1972, 1974a, 1976, 1978, 1980) and Khair Khana (Hackin 1936). This type of stamped decorations is normally dated to the Late Antiquity, i.e. from the $4^{\text {th }}$ to the $7^{\text {th }}$ century CE. For some sites, like Tepe Sardar, this type of ceramic is found even in the next period ( $7^{\text {th }}$ to $9^{\text {th }}$ century CE). According to Kuwayama (1991, p. 86), stamped ceramics such as this one were rarely discovered in the region of Gandhara and could be the result of a local production centred on the Kabul and Ghazni regions. 
Figure 13. Sherds with stamped decoration from Rgyalmo Khar, Dras Valley, Ladakh

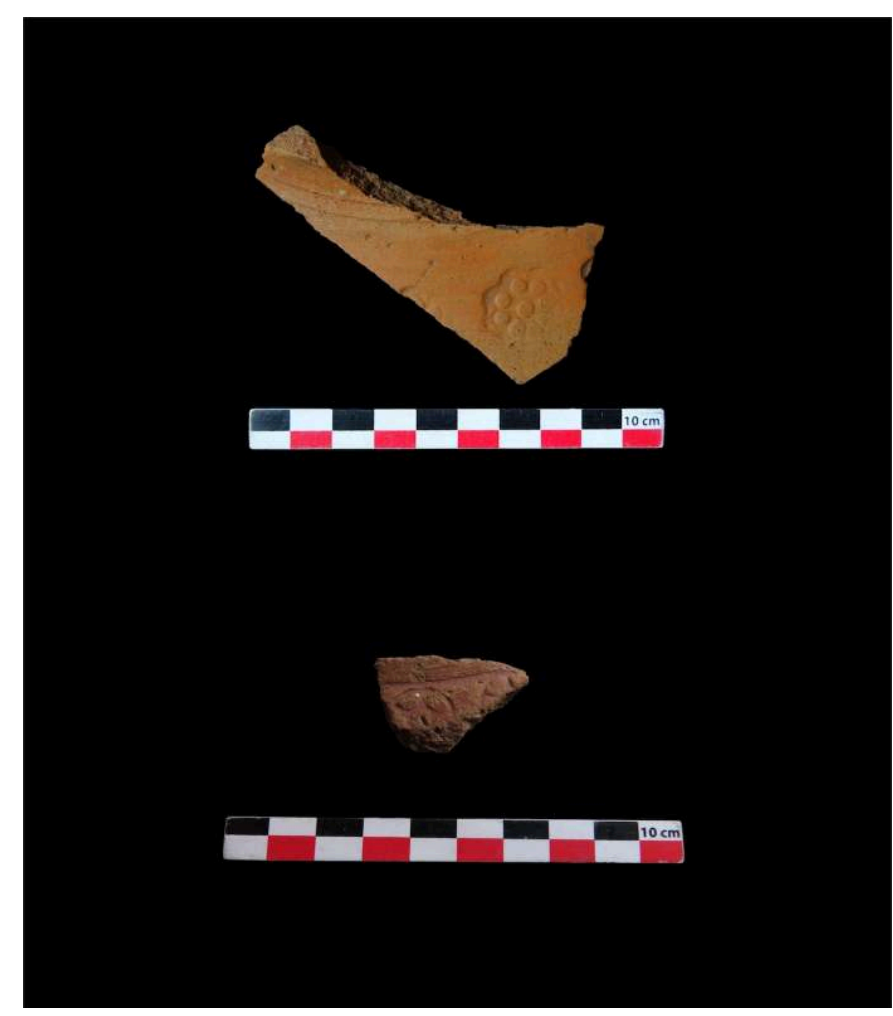

(c) Samara Broglia de Moura, 2017

33 Although stamped ware does not appear to have been found in large quantities in the Gandharan regions, other types of ceramics in Ladakh have parallels with the ceramics from this area. Several sherds from the Tingang ruins in Diskit (Nubra), dated to the post-Kushan period, show similarities with the site of Barikot in the Swat valley for Period IX ( $4^{\text {th }}$ to $8^{\text {th }}$ century CE) (Olivieri 2014): we find in both sites fine jars, globular bottles, bowls and basins shaped using rotation supports and finished with red slip cover (Bruneau 2014, p. 27, fig. 32 and p. 28, fig. 33).

The discovery of these ceramics in Purig and Nubra probably constitutes the first clear material link between Ladakh, Afghanistan and northern Pakistan, and suggests significant material and cultural exchanges between these regions during the Antiquity and late Antiquity over the Pamir and Hindukush ranges. It will be necessary to wait for more in-depth research in the regions bordering Ladakh to the west, such as Gilgit and Baltistan, to know if this type of ware was also produced there.

\section{Protohistory and Antiquity/Late Antiquity: a cultural partitioning of Ladakh?}

The geographical distribution of corded and Central Asian-influenced ceramics shows a clear material partition of Ladakh around the $1^{\text {st }}$ to $8^{\text {th }}$ century CE period (fig. 23). This east-west division mostly matches that observed by Zeisler (2011, p. 235) on linguistic grounds; according to her there are "non-tonal" conservative dialects in the northeastern and central areas (Baltistan, Purig, Lower Ladakh, Nubra and Leh) and "innovative" dialects in the southeastern areas (Upper Indus, Changthang and 
Zanskar). Furthermore, other elements of material culture have shown similar geographical differentiations. For instance, as Devers (2018, p. 104, fig. 2) pointed out clear influence from Central Asia can be seen in the form of rock inscription written in Brāhmī and Kharoșți in Purig and Lower Ladakh. According to the same author, forts built with stone ceilings, found mainly in Changthang and Upper Ladakh, are similar to those found in Western Tibet during Protohistory (Devers 2018, p. 104). Thus ceramics, dialects, fortifications, and rock inscriptions all point to a distinct cultural division of Ladakh in the past; we may see the region as a transitional area between the Central Asian and Western Himalayan spheres during that period.

\section{Early historical period}

The early historical period can be seen as roughly starting with the emergence of the Western Tibetan kingdom of Ngari Skorsum - of which Ladakh was a part - around the $10^{\text {th }}$ century CE. Pottery seems to change along with other elements of material culture; important evolutions also occurred with fortifications, religious sites and rock carvings. It appears to have been a period of important transformations for the Ladakhi society.

During this period, it is more common to find painted ceramics in the contexts of fortifications and Buddhist sites (monasteries and temples), whereas previously painted ware was more common in gravesites. For our study, at least 21 sites presented this type of pottery (fig. 14).

Figure 14. Sites with the presence of painted pottery in Ladakh

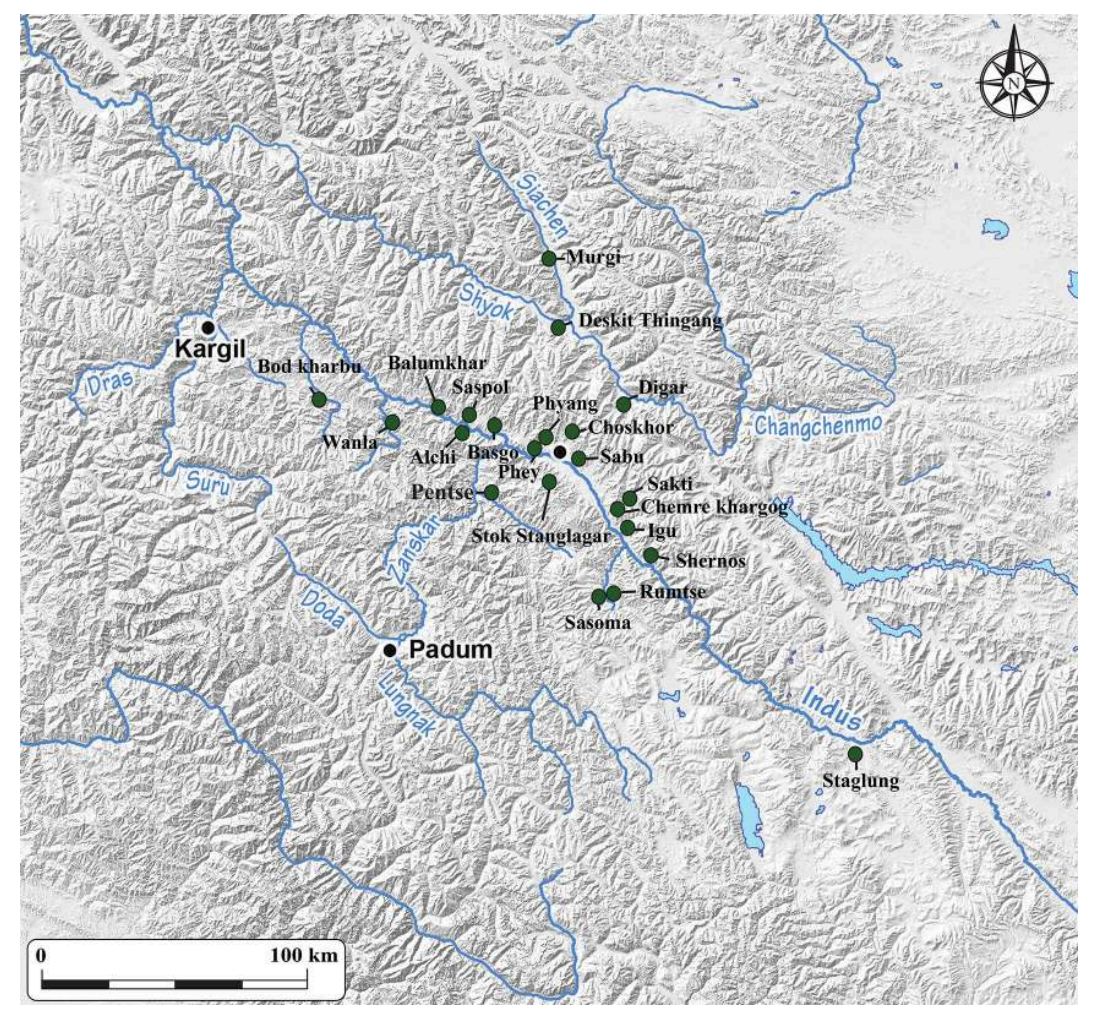

(C) Samara Broglia de Moura, 2018; map background Quentin Devers, 2016 
Painted ware is always hand-shaped, using mainly the coil and paddle technique ${ }^{33}$. Before the paint is added, the external surface of the pot is generally smoothened. The paint is made in free hand, and some of the paint can be applied without patterns, consisting only of patches of red paint. The colours are mainly dark or light red, but dark or light brown and orange also found (fig. 15). We can note three different types of decoration in painted ceramics: zigzag and line patterns are the most common, then come geometric and vegetable patterns in fewer numbers; finally a few ceramics have their surfaces fully painted (using large brushes).

Figure 15. Examples of painted pottery from Lower and Upper Ladakh

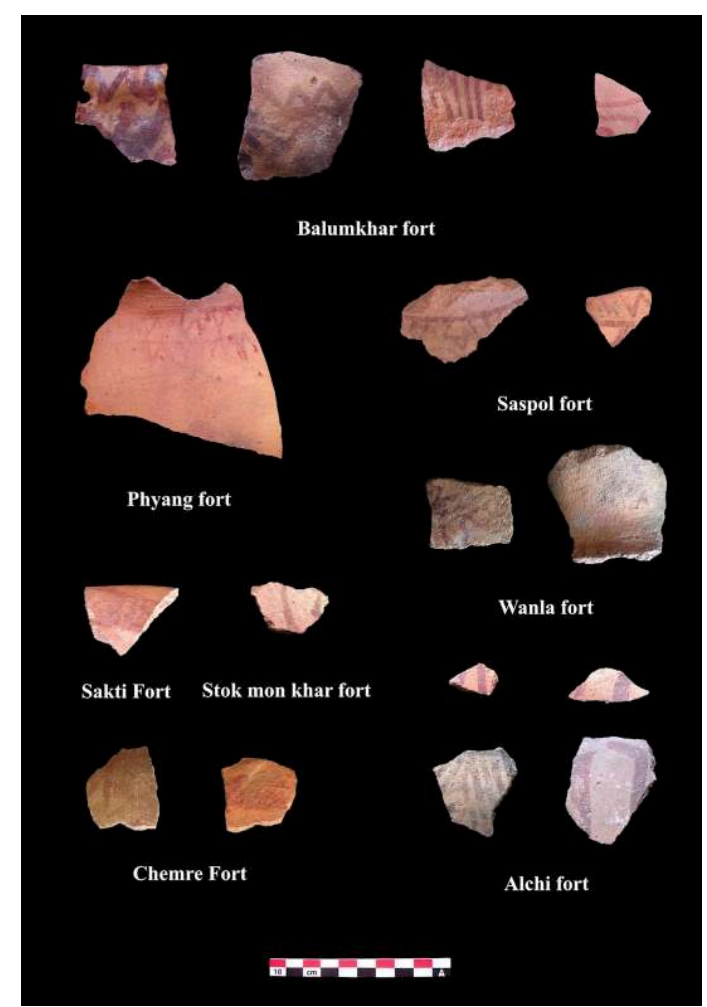

(c) Samara Broglia de Moura, 2018

The distribution of these types of painted patterns brings to light differences between Upper Ladakh, Lower Ladakh and Nubra. Zigzags, geometric and vegetables patterns are mostly observed in Lower Ladakh and Nubra, while in Upper Ladakh - and especially in the Chemre valley - we find the few known examples of fully painted pottery (fig. 16). The quantities of sherds found in both regions are very different as well. For instance, from the 74 sherds of painted pottery, 56 (76\%) were found in Lower Ladakh and Nubra, whereas only 18 (24\%) are from Upper Ladakh. This division between Lower and Upper Ladakh was already noticed by Howard (1999). 
Figure 16. Incidence of patterns in Lower and Upper Ladakh

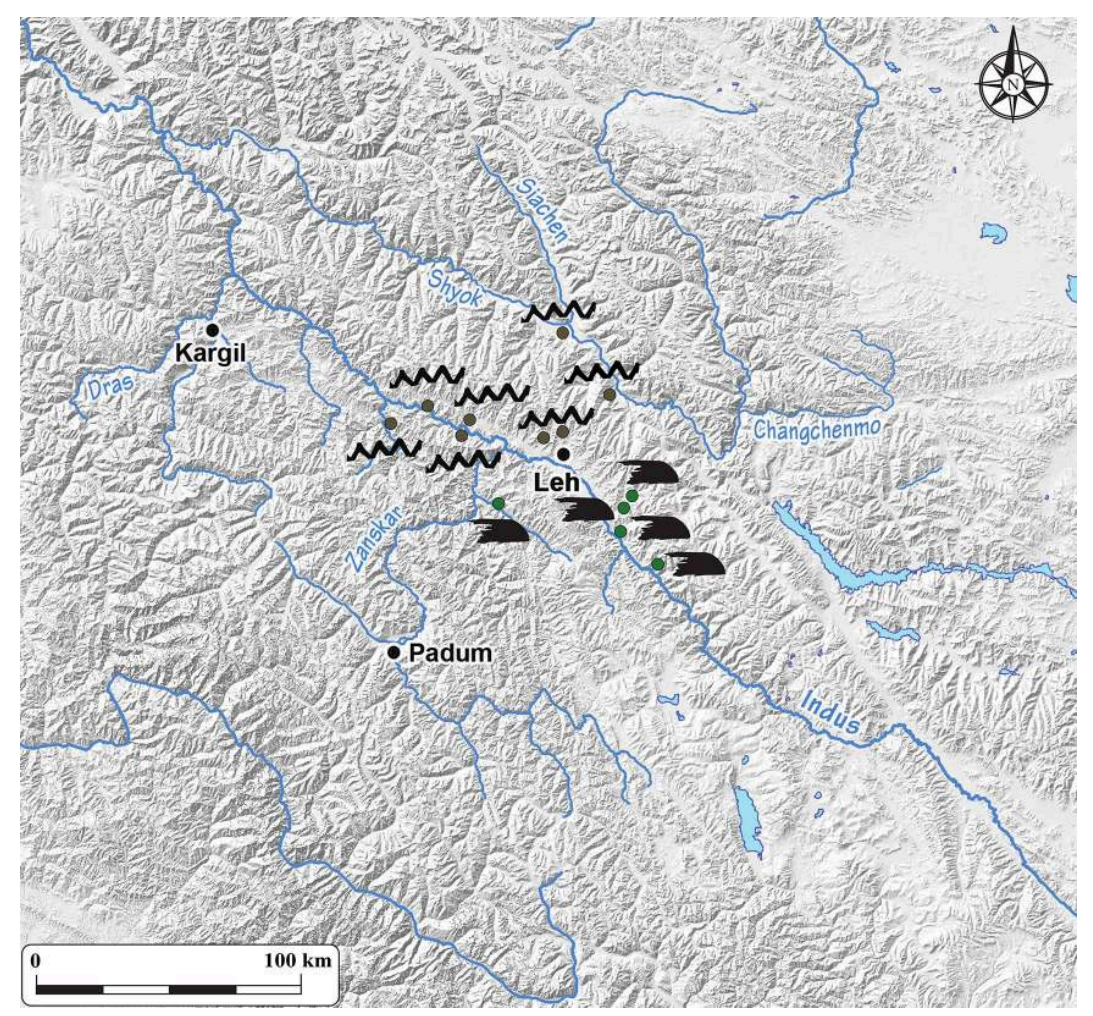

(C) Samara Broglia de Moura, 2019; map background Quentin Devers, 2016

In Lower Ladakh and Nubra, at the sites of Balumkhar, Alchi, Digar and Diskit, we find zigzag motifs on the internal face of the rim. There, rims were shaped by adding long lumps of clay to the pots' edges (fig. 17). Other types of ceramics observed on the sites where painted ware is found include, for instance, ceramics with open forms (such as bowls) and closed forms (such as jars and pots) (fig. 18). Vessels with open forms are found in small, medium and large sizes with pointed, flat and round lips; their diameters vary from $6 \mathrm{~cm}$ to $25 \mathrm{~cm}$. They are found in Balumkhar, Chemre (in the fort known as "Khargog" just before the monastery), Stok Mon Khar (better known as Stanglagar Khar) and Leh Choskhor. Ceramics with closed forms such as jars, storage jars and pots are found in almost all sites. The main types have middle necks and globular bodies. 
Figure 17. Rims with addition of clay and zigzag and curved line painted decoration in the inner part from Balumkhar and Alchi fort in Lower Ladakh and Digar in Nubra

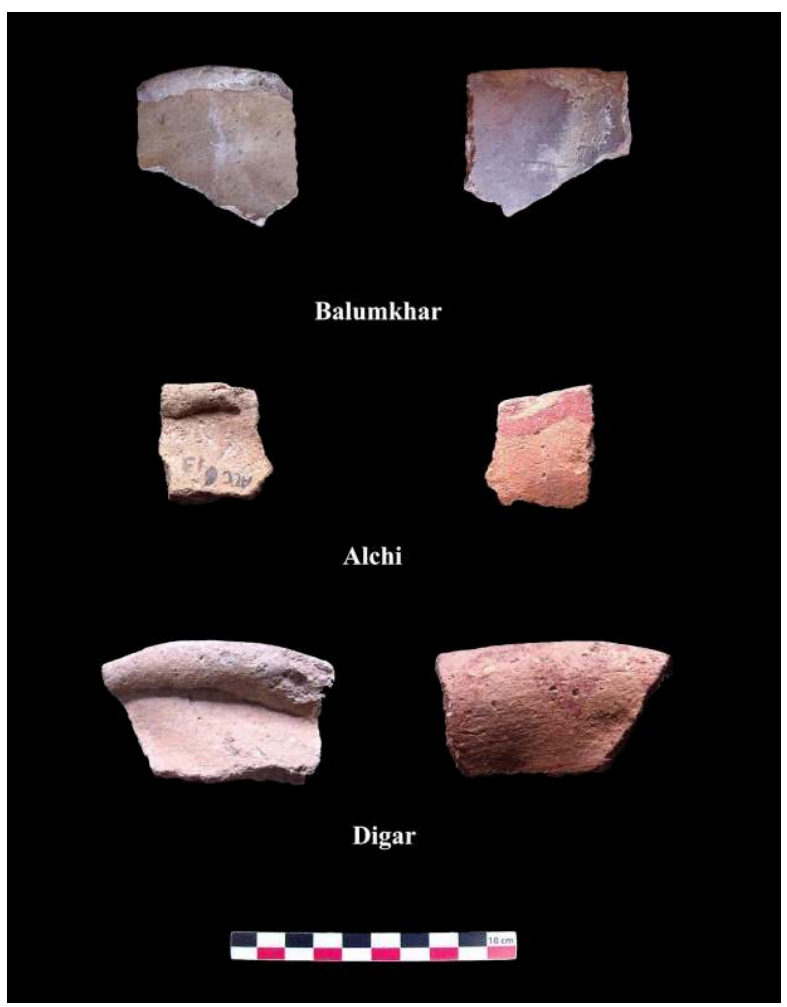

(C) Samara Broglia de Moura, 2018

Figure 18. Examples of open and restricted rim shapes from the early historical period Open forms
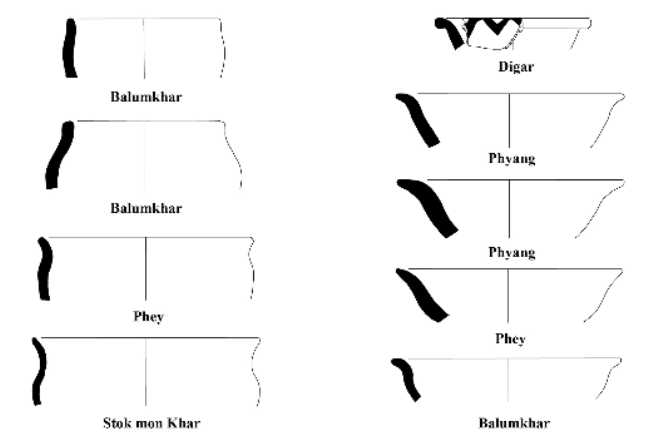

Restricted fornıs
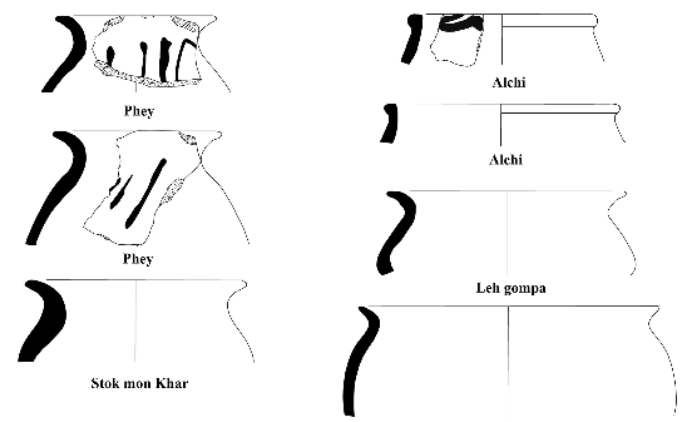

$-s^{\mathrm{scm}}$

Stok mon Khar

(c) Samara Broglia de Moura, 2018 
41 Painted pottery was also discovered in a stratigraphic context at the site of Leh Choskhor in Digur (Leh valley) (Bruneau \& Vernier 2015; Bruneau 2016). It was found in an occupation layer of temple 1, excavated in 2016 by MAFIL. The pots were observed in the same layers as the painted ceramic and typically have closed shapes: they consist of small globular pots and bowls with round bases and medium size necks (Bruneau 2016, p. 23, and p. 24, figs 31a, 31b). All of them show traces of burning, consistent with the layer of burnt soil where they were found. This could be the result of particular rituals performed in the temple (Bruneau 2016, p. 23), where bowls could have been placed over fire lit directly on the ground. The temple 1 at this site can be dated from the $11^{\text {th }}$ to the $13^{\text {th }}$ century CE (Bruneau 2016, p. 25).

The main collections of painted ware were found in six sites: in the forts of Balumkhar, Alchi, Saspol and Wanla (Lower Ladakh), in the fortified settlement of Digar in Nubra, and in the monastic ruin of Leh Choskhor (Upper Ladakh). Howard has suggested that Balumkhar was occupied from the $8^{\text {th }}$ to the $16^{\text {th }}$ century, although Takeuchi (2013, p. 51) later showed that the rock inscriptions on which the $8^{\text {th }}$ century early date was based should be reconsidered, instead proposing a more likely date of the $11^{\text {th }}$ or $12^{\text {th }}$ century. The other sites all belong to the period extending roughly from the $11^{\text {th }}$ to the $15^{\text {th }}$ century (Devers 2014 and 2016). In the light of these estimates, the first half of the second millennium CE can probably be regarded as the main period of production for this type of pottery. It is likely that these ceramics continued to be produced in small quantities in later periods as well, but then within the context of a new ceramic tradition that emerged in the late historical period.

\section{Late historical period}

The late historical period, in the context of this study, can be seen as starting around the time of the emergence of the Namgyal dynasty, i.e. around the $16^{\text {th }}$ century. The most emblematic site in the present corpus is the fortified complex of Basgo, known as Ratan Lhatse Khar. The precise dating of this pottery is very difficult, as the site was used over a considerable period of time. The ceramics from Basgo present more refined productions and more careful finishing. The diversity of shapes is much richer than in previous periods, with bowls, jars, storage jars as well as bottles and jugs (fig. 19). They all received careful smoothing on the exterior surfaces. One common type is the globular jar, with middle to high necks and a cordon appliqué between the neck and the shoulder (fig. 20). The latter feature was still seen at the beginning of the $20^{\text {th }}$ century on containers used for water or "beer" (Tib. chang) ${ }^{34}$ and is still found on pots used for puja rituals in Leh and other villages (fig. 21). Another site with abundant ceramics probably dating from this period is the fortification of Sumur Maral in Nubra, which was studied by Aurore Didier (Bruneau 2013 and 2014); several buildings of the site were C14-dated to the $17^{\text {th }}$ to $20^{\text {th }}$ century CE (Bruneau \& Vernier 2015, p. 5). 
Figure 19. Examples of open and restricted rim shapes from Basgo, Lower Ladakh
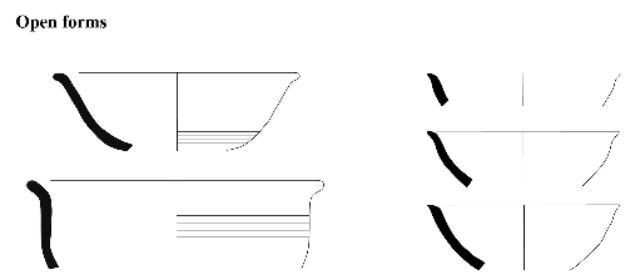

Restricted forms
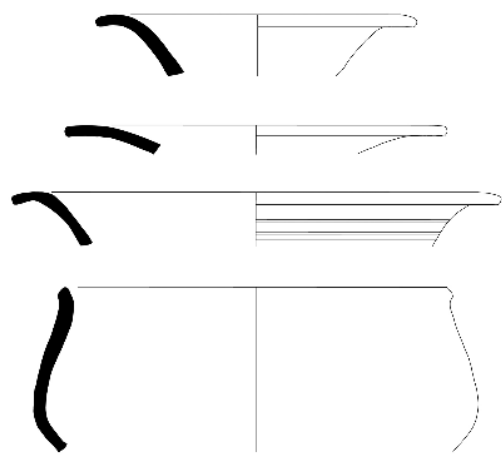

Bases/ foot

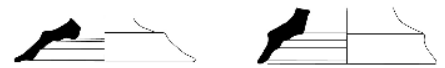

$-S^{s} \mathrm{~m}$

(C) Samara Broglia de Moura, 2018

Figure 20. Sherds with cordon appliqué between the neck and the shoulder from Basgo, Lower Ladakh

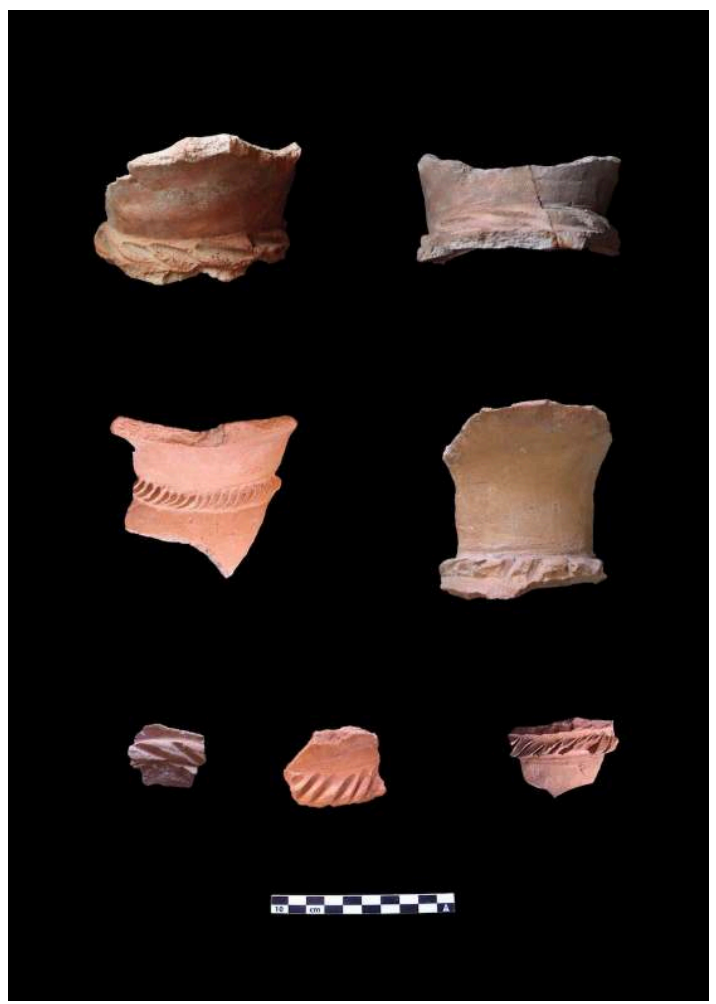

(C) Samara Broglia de Moura, 2016 
Figure 21. A reused globular jar with cordon appliqué in Chubi, Leh, Ladakh

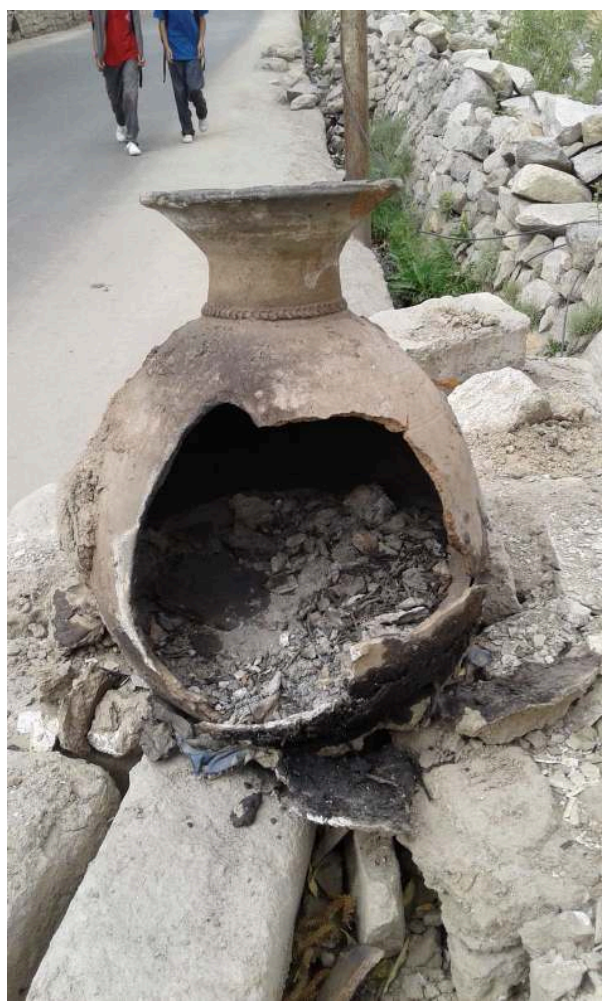

(C) Samara Broglia de Moura, 2016

\section{Conclusion}

Despite certain gaps in the chronology, research is starting to show general trends in the development of ceramic production in Ladakh (fig. 22), along with several of the extensive connections the region sustained with its neighbours over time.

Figure 22. Table of the pottery production changes over time in Ladakh

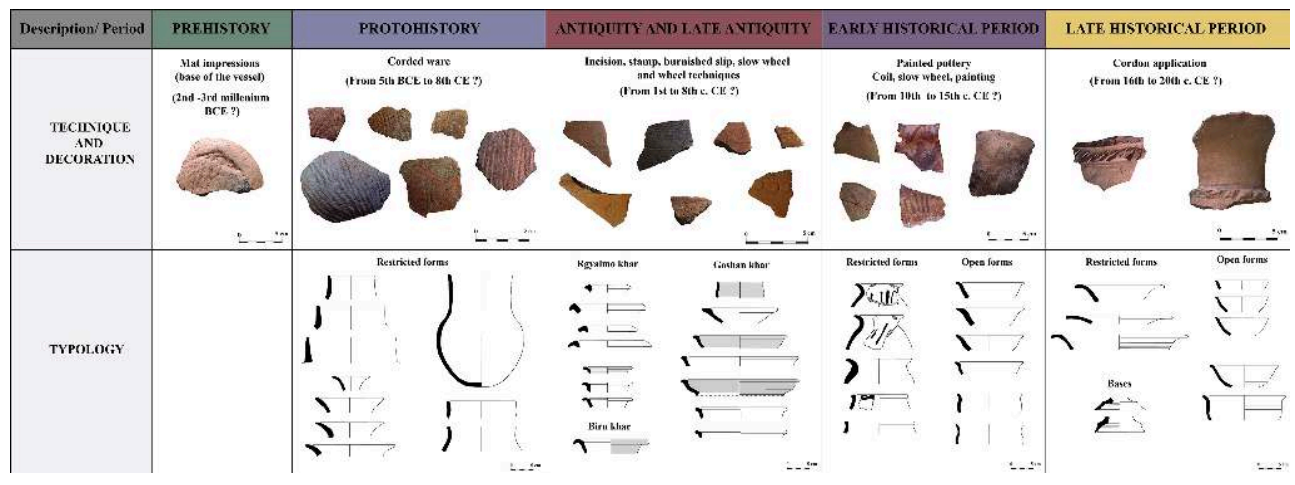

(C) Samara Broglia de Moura, 2019

Very little is known about ceramics during the Prehistoric period, as we only have a few sherds from the sites of Tirisa (Nubra) and Wakha (Purig). These sherds are similar 
to those from the sites of Burzahom and Gufkral in Kashmir during the $3^{\text {rd }}$ and $2^{\text {nd }}$ millennia BCE.

For the Protohistorical period, corded ware probably formed the most prominent type of ceramics in Ladakh. Found in Changthang, Upper Ladakh and Zanskar, it is an important sign of the integration of these areas into a larger material culture that spread over several regions of the Western Himalayas, such as Western Tibet, Spiti, Mustang and Uttarakhand. It is also during this period that painted ware might have first appeared in Ladakh, but this does not seem to have been nearly as widespread as it was during the early historical period.

In the Western parts of Ladakh, especially in Purig and Nubra, we find ceramics that present close connections with Central Asian pottery during what is referred to as Antiquity there. The use of the slow wheel and burnished slip are the most striking elements, clearly differentiating Purig and to a lesser extent Nubra from the rest of Ladakh and of the Western Himalayas in general. The presence of stamped and wave incisions for decoration finds parallels in the Kabul- Kapisa and Bactrian regions.

The corded wares observed in Changthang, Upper Ladakh and Zanskar, as well as the Central Asian influenced ceramics observed in Purig and Nubra, may well have coexisted (fig. 23) between the $1^{\text {st }}$ and $7^{\text {th }}$ centuries CE, before the Tibetan Empire extended its rule over Ladakh. However, the exact chronology of these two ceramic traditions in Ladakh needs to be confirmed in the future. Though no solid dates have been secured yet for corded ware in Ladakh, in Western Tibet it seems to go as far back as the $5^{\text {th }}$ century BCE, whereas Kushan ceramics can by definition go back only to the $1^{\text {st }}$ century CE. Whereas corded ware and Western Himalayan influenced painted wares are mostly associated with funerary sites, Central Asian influenced ceramics are mostly found in fortifications. 
Figure 23. Map showing the occurrence of corded and Central Asian wares in Ladakh

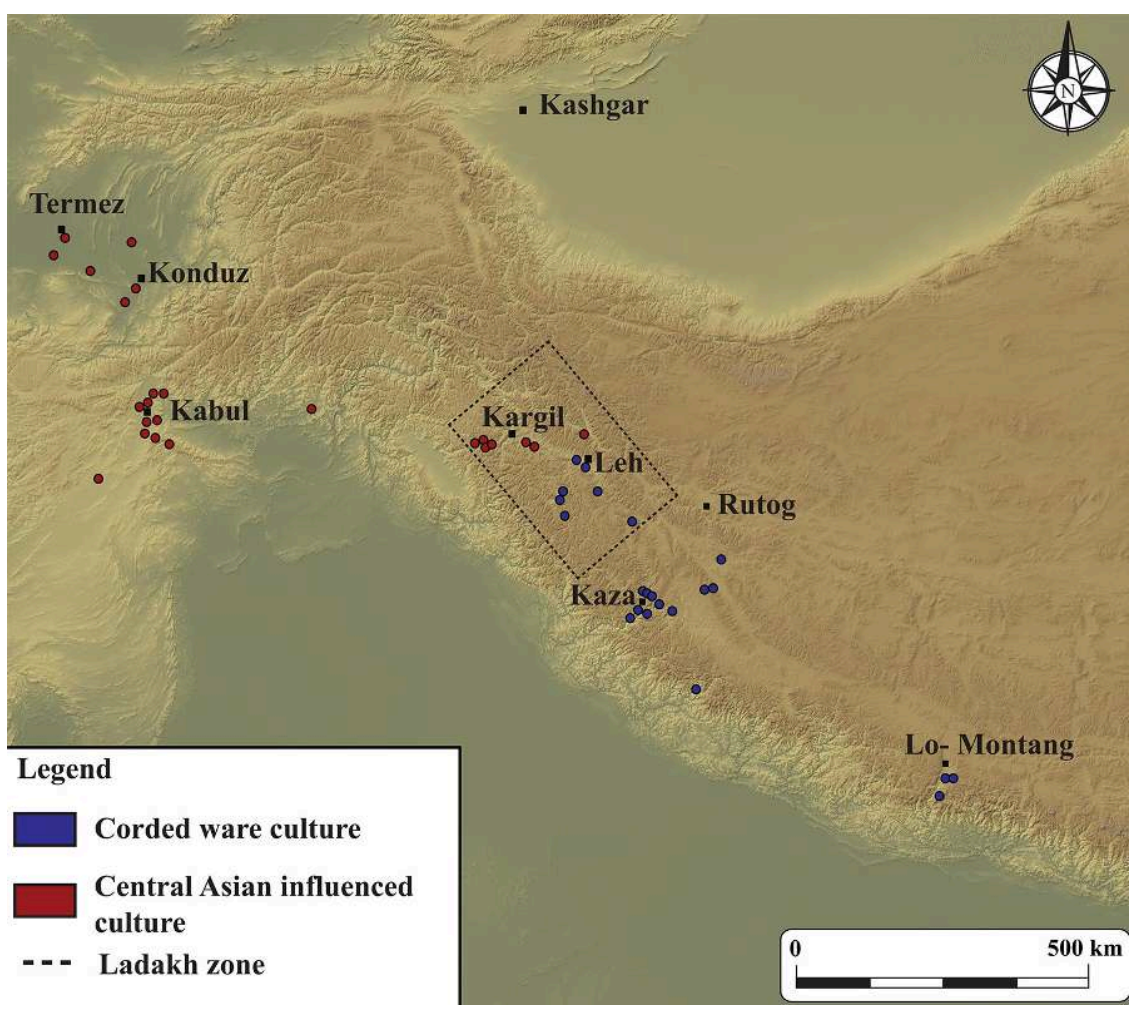

(c) Samara Broglia de Moura, 2019; map background Quentin Devers, 2016

49 The question of the exact geographical and chronological distribution of these traditions in Ladakh will be crucial to understanding the cultures present in the region during Protohistory and Antiquity. Considering the distribution of ceramics as well as fortifications, rock art, rock inscriptions and even dialects, there is a clear cultural division between the eastern and western parts of the region during this period. It appears that Ladakh was the territory where a transition between the Central Asian and Western Himalayan spheres took place during that time.

In the early historical period, we observe a multiplication of painted pottery in fortified and religious contexts. This type of ceramics probably appeared in the $10^{\text {th }}$ century, spread more widely in the $11^{\text {th }}$ century, and progressively faded away around the $16^{\text {th }}$ century. In the late historical period, new types and techniques of production are observed in Basgo. Some of these ceramics (globular jars with cordon appliqué on the neck, but without painted decoration) continued to be found until the $20^{\text {th }}$ century some are still being produced.

51 This article has presented a general overview of the different types of pottery found in the various areas of the region during different periods. As research continues, this broad typology will improve, along with our understanding of the history of Ladakh and the rich contacts the region developed with its neighbours.

\section{Acknowledgements}

52 This research would not have been possible without funding from the project Dynamiques Asiatiques, the Institut français d'études sur l'Asie centrale (IFEAC), the 
Centre de recherche sur les civilisations de l'Asie orientale (CRCAO), the École Pratique des Hautes Études (EPHE), the École française d'Extrême Orient (EFEO) and the Mission Archéologique Franco-Indienne au Ladakh (MAFIL).

I would like to thank Charles Ramble, Corinne Debaine-Francfort, Laurianne Bruneau, Sterenn Le Maguer for reading and commenting on this article and for all their constructive advice. I would like to thank the Franco-Indian Archaeological Mission in Ladakh and Archaeological Survey of India (Laurianne Bruneau, Martin Vernier, Simadri Bihari Ota and Tsering Phunchok) for all their help and advice during my fieldwork. Special thanks to Laurianne Bruneau with her administrative and research support and advice over all these years. Many thanks as well to Quentin Devers for showing me many important sites present in this article, and for all his essential help during my research. Also, all these years of fieldwork and research would not have been possible without the support of my Ladakhi colleagues and many friends. My sincere thanks to Tsewang Gonbo, Rigzin Falgon, Tsewang Norboo, Kunzes Dolma, Tsering Diskit, Stanzin Nurboo Samba, Jigmet Namgial, Pascale Dollfus, Marion Poux and Nils Martin.

\section{BIBLIOGRAPHY}

Aldenderfer, M. 2007 Defining Zhang Zhung ethnicity. An archaeological perspective from far Western Tibet, in A. Heller \& G. Orofino (eds), Discoveries in Western Tibet and Western Himalayas. Essays on History, Literature, Archaeology and Art. Proceedings of the $10^{\text {th }}$ Seminar of the International Association of Tibetan Studies (Leiden, Brill), pp. 1-21.

Aldenderfer, M. \& H. Moyes 2004 Excavation at Dindun, a pre-Buddhist village site in far Western Tibet, in W. Hou \& L. Yongxian (eds), Proceedings of the First International Conference on Tibetan Archaeology and Art (Chengdu, Center for Tibetan Studies, Sichuan University Chengdu), pp. 47-68.

Aldenderfer, M. \& Z. Yinong 2004 The prehistory of the Tibetan Plateau to the seventh century A.D. Perspectives and research from China and the West since 1950, Journal of World Prehistory 18(1), pp. 1-55.

Anonymous 1964 Excavation at Burzahom, district Srinagar, Indian Archaeology 1961-62 - A Review, pp. 17-21.

1965 Excavation at Burzahom, district of Srinagar, Indian Archaeology 1962-63 - A Review, pp. 9-10.

Balfet, H., M.-F. Fauvet-Berthelot \& S. Monzon 1983 Pour la normalisation de la description des poteries (Paris, CNRS).

1988 Lexique plurilingue pour la description des poteries (Paris, CNRS).

Bandey, A. A. 2009 Prehistoric Kashmir. Archaeological History of Palaeolithic and Neolithic Cultures (Delhi, Dilpreet Publishing House).

Beal, S. 1884 Si-Yu-Ki. Buddhist Records of the Western World, vol. 1 (London, Trübner \& Co., Lundgate Hill). 
Bellezza, J. 2016 The ancient burial sites of Spiti. The indigenous socioeconomic and cultural order and trans-regional communications in the era before the spread of Buddhism, Flight of the Khyung [online, URL: http://www.tibetarchaeology.com/january-201, accessed 10 September 2017].

Bhatt, R. C., K. L. Kvamme, V. Nautiyal, K. P. Nautiyal, S. Juyal \& S. C. Nautiyal 2008-2009 Archaeological and geophysical investigation of high mountain cave burials in Uttarakhand Himalaya, India, Studies in South Asian Art and Archaeology 30, pp. 1-16.

Bruneau, L. 2010 Le Ladakh (Jammu \& Cachemire, Inde) de l'Âge du Bronze à l'introduction du bouddhisme. Une étude de l'art rupestre. PhD thesis in archaeology (Paris, Université de Paris 1 Panthéon Sorbonne).

(in collaboration with M. Vernier, A. Didier, S. Monnier, C. Gaillard, H. Forestier, Q. Devers \& C. Camerlynck) 2013 Mission Archéologique Franco-Indienne au Ladakh: rapport préliminaire, campagne 2013 [online, URL : http://www.mafil.org/wp-content/uploads/2016/03/MAFIL-rapportcampagne-2013-web-FR.pdf, accessed 15 December 2017]. (in collaboration with A. Didier, M. Vernier, Q. Devers \& J. Suire) 2014 Mission Archéologique Franco-Indienne au Ladakh: rapport saison 2014 [online, URL : http://www.mafil.org/wp-content/ uploads/2016/03/MAFIL-rapport-campagne-2014-web-FR.pdf, accessed 16 December 2017]. (in collaboration with M. Vernier, S. Bickelmann, S. Broglia \& M. Poux) 2016 Mission Archéologique Franco-Indienne au Ladakh: Report Fieldwork 2016 [online, URL : http://www.mafil.org/wp-content/ uploads/2016/06/MAFIL-2016-online-report.pdf, accessed 15 December 2017].

Bruneau, L. \& M. Vernier (in collaboration with J. Suire, S. Broglia \& R. Silveston) 2015 Mission Archéologique Franco-Indienne au Ladakh: rapport saison 2015 [online, URL : http://www.mafil.org/ wp-content/uploads/2016/03/MAFIL-rapport-campagne-2015.pdf, accessed 16 December 2017].

Chauhan, H., M. Dowad \& T. Norbu 2014 Spiti valley. A preliminary archaeological investigation, Manimahesh: a journal of Himalayan studies 5, pp. 24-31.

Chauhan, H. \& P. M. Saklani 2015 Archaeological excavation at Kibber, Lahaul and Spiti. Manimahesh: a journal of Himalayan studies 6, pp. 11-15.

Chinese Institute of Tibetology, Sichuan Universit 2001a Trial excavation of ancient tombs on the Piyang-Donggar site in Zanda county, Tibet, Kaogu 6, pp. 14-31.

2001 b Survey of the Gebusailu cemetery in Zanda county, Tibet, Kaogu 6, pp. 39-44.

2015 New discoveries at Gurgyam cemetery and Chuvthag cemetery in Ngari, Tibet, Kaogu 7, pp. 29-51.

Clarke, G. E. 1977 Who were the Dards? A review of the ethnographic literature of the northwestern Himalaya, Kailash: a journal of Himalayan studies 5(4), pp. 323-356.

Denwood, P. 2008 The Tibetans in the West, part I, Journal of Inner Asian Art and Archaeology 3, pp. 7-21

Denwood, P. T \& N. Howard 1990 Inscription at Balukhar and Char Zampa and archaeological observations on the fort of Balukhar and its environs, in T. Skorupski (ed), Indo-Tibetan Studies. Papers in honour and appreciation of Professor David L. Snellgrove's contribuition to Indo-Tibetan Studie (Tring, Institute of Buddhist Studies), pp. 81-88.

Devers, Q. 2014 Les fortifications du Ladakh, de l'âge du bronze à la perte d'indépendance (1683-1684 d.n.è). PhD thesis in archaeology (Paris, École Pratique des Hautes Études). 2016 Fortifications of Ladakh. A brief chrono-typology, in R. Linrothe \& H. Poell (eds), Visible Heritage. Essays on the Art and Architecture of Greater Ladakh (New Delhi, Studio Orientalia), pp. 41-64. 
2018 Archaeological Ladakh. Recent discoveries redefining the history of a key region between the Pamirs and the Himalayas, Central Asiatic Journal 61, pp.103-132.

Duncan, J. E. 1906 A Summer Ride through Western Tibet (London, Smith, Elder \& Co). [online, URL: https://archive.org/details/cu31924023017704/page/n11, accessed 12 October 2020].

Dupont-Delaleuf, A. 2011 Styles techniques des céramiques de la protohistoire en Asie centrale. Méthodologie et étude de cas. PhD thesis in archaeology (Paris, Université de Paris Ouest-La défense).

Engel, N. 2012. Mes Ayna. Fouilles de l'Institut afghan d'archéologie (2009-2012). MA thesis in archaeology (Paris, École des Hautes Études en Sciences Sociales).

Fonia, R. S. 1993 Ladakh corridor to Central Asia. An investigative report of prehistoric cultures, The Journal of Central Asian Studies 4(1), pp. 35-42.

Francke, A. H. 1905 Archaeological notes on Balu-mKhar in Western Tibet, Indian Antiquary. A Journal of Oriental Research 34, pp. 203-219.

1906. Inscriptions at Saspola, Indian Antiquary. A Journal of Oriental Research 35, pp. 325-336. [1914] 1994 Antiquities of Indian Tibet, part 1, Personal Narrative (New Delhi, Archaeological Survey of India).

[1914] 2002 Historical documents from the borders of Tibet, in J. Ph. Vogel (ed.), Archaeological Survey of India, Annual Report 1909-1910 (New Delhi, ASI), pp. 104-112.

Fussman, G. \& M. Le Berre, 1976 Monuments bouddhiques de la région de Caboul, vol. 1, Le monastère de Gul Dara (Caboul/Paris, Délégation archéologique française en Afghanistan/de Boccard, Mémoires de la Délégation archéologique française en Afghanistan 22).

Ghirshman, R. 1946 Begram. Recherches archéologiques et historiques sur les Kushans (Le Caire, Institut français d'archéologie orientale, Mémoires de la Délégation Archéologique Française en Afghanistan 12).

Hackin, J. 1936 Recherches Archéologiques au col de Khair Khaneh près de Kaboul (Paris, Éditions d'art et d'histoire, Mémoires de la Délégation archéologique française en Afghanistan 7).

Hackin, J., J. Carl \& J. Meunié 1959 Diverses recherches archéologiques en Afghanistan (Paris, Presses universitaires de France, Mémoires de la Délégation archéologique française en Afghanistan 8).

Higuchi, T. \& S. Kuwayama 1970 Chaqalaq Tepe. Fortified Village in North Afghanistan Excavated in (1964-1967) (Kyoto, Emeritus Sellchi Mizuno/Kyoto University).

Howard, N. 1989 The development of the fortresses of Ladakh c. 950 to c. 1650 A.D., East and West 39(1-4), pp. 217-288.

1999 Ancient painted pottery from Ladakh, in M. van Beck \& P. Brixbertels Enpederson (eds), Ladakh Culture, History and Development between Himalaya and Karakoram (Aarhus, Aarhus University Press) pp. 222-236.

Huttel, H.-G. \& I. Papp 1998 On the chronology and periodization of Khyinga settlement mountain, in Beiträge Zur Allgemeinen und Vergleichenden Archäologie. (Mainz, Verlag Phillip von Zarbern), pp. 5-26.

Kuwayama, S. 1972 The first excavation at Tapa Skandar, Archaeological Survey in Kyoto University in Afghanistan 1970, pp. 5-14.

1974a Excavation at Tapa Skandar. Second interin report, Kyoto University Archaeological Survey in Afghanistan 1972, pp. 5-13.

1974b Kapisi Begram III. Renewing its Dating, Orient 10, pp. 57-78.

1976 The third excavation at Tepe Skandar, Japan-Afghanistan Joint Archaeological Survey in 1974, 
pp. 5-15.

1978 The fourth excavation at Tapa Skandar, Japan-Afghanistan Joint Archaeological Survey in 1976, pp. 5-12.

1980 The fifth excavation at Tapa Skandar, Japan-Afghanistan Joint Archaeological Survey in 1978 pp. 5-15.

1991 The horizon of Begram III and beyond. A chronological interpretation of the evidence for monuments in the Kapisa - Kabul - Ghazni Region, East and West 41(1), pp. 79-120.

2002 A new date for Begram III, in S. Kuwayama, Across the Hindukush of the first Millennium. A Collection of Papers (Kyoto, Institute for Research in Humanities, Kyoto University), pp. 162-172.

Lerner, J.-A. 2018 A prolegemenom to the study of pottery stamp from Mes Aynak, Afghanistan 1(2), pp. 239-256.

Lyonnet, B. 1997 Céramique et peuplement du Chalcolithique à la conquête arabe, in J.-C. Gardin (ed.), Prospections archéologiques en Bactriane orientale (1974-1978), vol. 2 (Paris, Recherche sur les civilisations, Mémoires de la mission française en Asie centrale 8).

Meunié, J. 1942 Shotorak (Paris, Les éditions d'art et d'histoire, Mémoires de la Délégation Archéologique Française en Afghanistan 10).

Nautiyal, V., R. C. Bhatt, P. M. Saklani, V. M. Tripathy, C. M. Nautiyal \& H. Chauhan 2014 Lippa and Kanam. Trans-Himalayan cist burial culture and pyrotechnology in Kinnaur, Himachal Pradesh, India, Antiquity 88(339).

Olivieri, L. M. 2014 The Last Phases of the Urban site of Bir-Kot-Ghwandai (Barikot). The Buddhist sites of Gumbat and Amluk-Dara (Barikot) (Lahore, Sang-e-Meel Publications).

Ota, S. B. 1993 Evidences of transhumance from Ladakh Himalayas, Jammu and Kashmir, and India, Advances in Indian Archaeology 1, pp. 91-110.

2018 Prehistory of Ladakh Himalayas, Jammu and Kashmir, History Today: Journal of History and Historical Archaeology 19, pp. 10-20.

Paiman, Z. 2013 Tepe Narenj à Caboul, ou l'art bouddhique à Caboul au temps des incursions musulmanes (Paris, Collège de France/de Boccard, Publications de l'Institut de civilisation indienne 82).

Papp, I. 2002 Die Keramik von Khyinga. Mustang District, Nepal. PhD Thesis in archaeology. (Bonn, Bonn University).

Roux, V. 1994 La technique du tournage. Définition et reconnaissance par les macrotraces, in F. Audouze \& D. Binder (eds), Terre cuite et société. La céramique, document technique, économique, culturel. Actes des XIV ${ }^{\mathrm{e}}$ Rencontres d'archéologie et d'histoire d'Antibes (Juan-lesPins, Association pour la promotion et la diffusion des connaissances archéologiques), pp. 45-58. 2017 Des céramiques et des hommes. Décoder les assemblages archéologiques (Nanterre, Presses universitaires de Paris Nanterre).

Roux, V. \& A. Courty 1995 Identification of wheel throwing on the basis of ceramic surface features and microfabrics, Journal of Archaeological Sciences 22, pp. 17-50.

Rye, O. S. 1981 Pottery Technology. Principles and Reconstructions (Washington, Taraxacum, Manuals on Archaeology 4).

Sharma A. K. 2013. Excavation at Gufkral (Jammu and Kashmir) (Delhi, B.R. Publishing Corporation). Shepard, A. 1968. Ceramic for the Archaeologist (Washington, Carnegie Institution of Washington). Simons, A., W. Schön \& S. Sagar Shrestha 1994a Preliminary Report on the 1992 Campaign of the Team of the Institute of Prehistory, University of Cologne, Ancient Nepal 136, pp. 52-75. $1994 \mathrm{~b}$ The prehistoric settlement of Mustang. First results of the 1993 archaeological 
investigations in cave systems and connected ruined sites, Ancient Nepal 137, pp. 93-129. 1998 Archaeological research in Mustang. Report on the fieldwork of the years 1994 and 1995 done by the Cologne University team, Ancient Nepal 140, pp. 65-83.

Singh, E. \& P. M. Saklani 2017 A preliminary investigation of the burial sites in Spiti valley in Himachal Pradesh, India, Shodh Patrika 68(3-4), pp. 29-43.

Taddei, M. 1968 Tapa Sardar. First Preliminary Report, East and West 18(1-2), pp. 109-124.

Takeuchi, T. 2013 Old Tibetan rock inscriptions near Alchi, in T. Takeuchi \& H. Noihiko (eds), Historical Development of the Tibetan Languages, Journal of Research Institute 49, pp. 29-69.

Van der Leeuw, S. 1993 Giving the potter a choice. Conceptual aspects of the pottery techniques, in P. Lemmonier (ed.), Technological Choices. Transformation in Material Cultures since the Neolithic (London/New York, Routledge), pp. 238-288.

Veuve, S. 1974 La céramique de Kohna Masdjid (Afghanistan). MA Thesis in archaeology (Bordeaux, Université de Bordeaux).

Zeisler, B. 2010 East of the moon and west of the sun? Approaches to a land with many names, north of ancient India and south of Khotan, The Tibet Journal 35(2), pp. 1-73.

2011 Kenhat, the dialects of Upper Ladakh and Zanskar, in M. Turin \& B. Zeisler (eds), Himalayan Laguages and Linguistics. Studies in Phonology, Semantics, morphology and Syntax (Leiden/Boston, Brill), pp. 235-301.

\section{NOTES}

1. According to Francke (2002, p. 105), the inhumation consisted in cutting the body into pieces and inserting it into the pottery.

2. The official history of the Sui dynasty, completed in $636 \mathrm{CE}$.

3. For further information on the "Empire of Eastern Women" see Zeisler 2010 and Denwood 2008.

4. He also dated the grave he had seen in Gya to the same period: Francke 1994, p. 65.

5. It should be noted that the painted patterns of the sherds from the Leh tomb are different from those found in Balumkhar.

6. The dating given by Howard was based on the inscription of Balumkhar (dated by him and Denwood to the Tibetan empire), and on a painted sherd found inside the rammed earth wall which he dates to the middle of the $16^{\text {th }}$ century. However, the inscriptions in Balumkhar appear to be later than the date proposed by Denwood and Howard (1990) (probably $11^{\text {th }}$ century), whereas the rammed earth wall is probably earlier than stated by Howard, as this material was already in use during the $8^{\text {th }}$ to $12^{\text {th }}$ centuries (Devers 2016). If we follow these chronological considerations, it seems that painted pottery was not produced over as long a period of time as originally put forward by Howard.

7. The "Mission Archéologique Franco-Indienne au Ladakh" (MAFIL) has been co-directed by Laurianne Bruneau and S. B. Ota (2013-2015) and Tsering Phunchok (2016).

8. Aurore Didier (Researcher at the Laboratory "Archéologies et Sciences de l'Antiquité"ArScAn/CNRS). The study was assisted by R. Kumar, F. Villette, H. J. Barapatre, D. Kumar and M. Vernier.

9. As the MAFIL is a cooperation project with the ASI, all the archaeological material collected during the campaigns is stored at the office of the Archaeological Survey of India in Leh. 
10. I would like to thank Simadri Bihari Ota (former Regional Director of ASI, Bhopal) and Tsering Punchok (Director of ASI office in Leh) to allow me to study the pottery collection at the ASI in Leh.

11. In addition to this collection, 665 sherds (of which 388 are diagnostics) were studied in adjacent areas of Ladakh.

12. The technological study was mainly based on the work of Rye 1981; Dupont-Delaleuf 2011; Van der Leeuw 1993; Roux 1994, 2017 and Roux \& Courty 1995. For decoration see Shepard 1968.

13. Near the Saser-la pass S. B. Ota $(2018$, p. 17) has discovered a site from $8500 \mathrm{BCE}$ and c. 7300 BCE (c. 10500 and 9300 years before present). Other prehistoric sites (Giak and Kiari) were studied by S. B. Ota (1993) in the 1990s as mentioned before.

14. This information was obtained during the lecture by Aurore Didier in the seminar of the "Centre de recherche sur les civilisations de l'Asie orientale": Didier, A. 2014 "La céramique de la Nubra: éléments de caractérisation techno-stylistique et première classification typologique".

15. This information was also obtained during the lecture by Aurore Didier cited in the previous note.

16. I would like to thank Anna Szeredi and Irimias Balazs for the information.

17. Daraut-Kurgan, Eilatan, Dalverzin, Šaštepe, Afrasiab, Koktepe, and Džarkutan in Uzbekistan Kangurtut in Tadjikistan, Begaš in Kazakhstan, and Loebanr in Pakistan.

18. New sites recently documented during surveys conducted for the Indian National Trust for Art and Cultural Heritage (INTACH) by Quentin Devers display important concentrations of corded ware in eastern Changthang, at Ronggo and Anley.

19. Malakhartse is the only site where we did not find any graves. The term graveyard is commonly used in Ladakh for this type of structure. However, these structures have never been excavated before to know their exactly function.

20. The location of these pots is currently not known. Also, it is important to note that Francke also describe sherds with "linear ornaments impressed" in Kalagtrunga (in Poo, Spiti) and Bhaghag Khar (in Khaltse, Ladakh): Francke 1994, p. 114.

21. The item was studied at the site and left in situ.

22. Chinese Institute of Tibetology 2015.

23. Aldendefer \& Moyes 2004; Aldenderfer \& Yinong 2004; Aldenderfer 2007.

24. Chinese Institute of Tibetology 2001a, 2001b.

25. Huttel \& Papp 1998; Papp 2002.

26. Simons et al. 1994a and 1994b.

27. Simons et al. 1994a, 1994b, 1998.

28. Bellezza 2016; Singh \& Saklani 2017; Chauhan et al. 2014; Chauhan \& Saklani 2015.

29. Bhatt et al. 2008-2009, p. 7. The site of Malari does not present corded ware, but the typology and decoration of the ceramics are similar to those found in Ghuvthag (see also Nautiyal et al. 2014).

30. It is impossible at this moment to know exactly if all the examples of pottery were fabricated by the padding technique or a combination of techniques.

31. Thicker strings were used in earlier periods (late $4^{\text {th }} /$ early $5^{\text {th }}$ to early $8^{\text {th }}$ century CE) and thinner strings in later periods (between the $8^{\text {th }}$ and the $10^{\text {th }}$ century CE).

32. Combination of clay and water applied to the vessel surface before firing.

33. Coil technique consists in making rolls of less or more uniform thickness and place them around a circumference and gradually build up a vessel. Plate technique consist in making flat slabs and join them by pressing and gradually building up the vessel (Rye 1981, pp. 66, 71).

34. Information given by Rigzin Dordjei, from Heneskut village. A ceramic with cord incisions was produced by his grandfather. In Likir, Lamchung Tsepeil (Ganajora house) also related that this type of jar was made by his grandfather, but because of absence of demand today it is not produced anymore. It is possible that the production of this type of vessel in Likir ceased when 
Ieshi Norup (Apiso house) introduced a new type of decoration around the 1970s, that still can be seen in Likir today, starting a new generation of ceramic production there.

\section{ABSTRACTS}

This paper aims to provide a brief overview of the research that has been carried out since 2015 on the ancient ceramics of Ladakh. Since this date, surveys and studies of pottery were conducted in 60 archaeological sites in four sub-regions of Ladakh: Lower and Upper Ladakh, Changthang, Purig and Zanskar. This research aims, first of all, to demonstrate the changes of production during the different periods and the material and cultural relations that Ladakh has had with its neighbours in different chronological frameworks.

Cet article vise à donner un bref aperçu de la recherche menée depuis 2015 sur les céramiques du Ladakh. Depuis cette date, des prospections et des études de la céramique ont été menées sur 60 sites archéologiques répartis dans cinq sous-régions du Ladakh : le Bas et Haut Ladakh, le Changthang, le Purig et le Zanskar. Cette recherche vise à démontrer les aspects diachroniques et synchroniques des céramiques du Ladakh, c'est-à-dire les changements de productions durant les différentes périodes et les relations matérielles et culturelles que le Ladakh a pu avoir avec ses voisins dans différents cadres chronologiques.

\section{INDEX}

Mots-clés: céramique, prospection, chronologie, Ladakh

Keywords: ceramics, survey, chronology, Ladakh

\section{AUTHOR}

\section{SAMARA BROGLIA DE MOURA}

Samara Broglia de Moura is a PhD candidate in archaeology at the École Pratique des Hautes Études (EPHE, PSL Research University, CRCAO/ArScAn) under the direction of Charles Ramble (EPHE) and Corinne Debaine-Francfort (CNRS). She focuses on the ceramics of Ladakh, as well as the material and cultural interactions with Central Asia, Tibet and India. Since 2011, she has participated in several missions in Central Asia (Afghanistan, Uzbekistan, Turkmenistan) as well in India and Nepal. Since 2015, she has been carrying out material studies at the site of Leh Choskor for MAFIL (Franco-Indian Archaeological Mission in Ladakh). samara.broglia@gmail.com 